

\title{
Non-traditional isotope perspectives in vertebrate palaeobiology
}

Jérémy Martin, Theo Tacail, Vincent Balter

\section{To cite this version:}

Jérémy Martin, Theo Tacail, Vincent Balter. Non-traditional isotope perspectives in vertebrate palaeobiology. Palaeontology, 2017, 60 (4), pp.485-502. 10.1111/pala.12300 . hal-01648311

\section{HAL Id: hal-01648311 \\ https://hal.science/hal-01648311}

Submitted on 19 May 2018

HAL is a multi-disciplinary open access archive for the deposit and dissemination of scientific research documents, whether they are published or not. The documents may come from teaching and research institutions in France or abroad, or from public or private research centers.
L'archive ouverte pluridisciplinaire HAL, est destinée au dépôt et à la diffusion de documents scientifiques de niveau recherche, publiés ou non, émanant des établissements d'enseignement et de recherche français ou étrangers, des laboratoires publics ou privés. 


\title{
Non-Traditional Isotope perspectives in vertebrate palaeobiology
}

by JEREMY E. MARTIN ${ }^{1 *}$, THEO TACAIL ${ }^{1}$, and VINCENT BALTER $^{1}$

${ }^{1}$ Université Lyon, ENS de Lyon, Université Lyon 1, CNRS, UMR 5276 Laboratoire de Géologie de Lyon: Terre, Planète, Environnement, F-69342 Lyon, France; e-mails: jeremy.martin@ens-lyon.fr, theo.tacail@ens-lyon.fr, vincent.balter@ens-lyon.fr

* Corresponding author

\begin{abstract}
The recent development of Multi-Collector Inductively Coupled Plasma Mass Spectrometry (MC-ICPMS), notably in the disciplines of earth sciences, now allows the measurement of precise isotope ratios, even under low concentration. Nontraditional isotope systems, such as alkaline earth $(\mathrm{Ca}, \mathrm{Mg})$ and transition $(\mathrm{Cu}, \mathrm{Fe}, \mathrm{Zn})$ metals are now being measured in a variety of biological tissues, including bone and teeth. Although our understanding of the environmental and biological mechanisms behind the fractionation of such elements is still in its infancy, some of these isotopes are suspected to fractionate along the food chain as has been reported in the literature for calcium, magnesium and zinc. Other geochemical methods, such as concentration analyses permit a prior assessment of diagenesis in the fossils to be analysed and such an approach allows recognising that in some circumstances, not only enamel but also dentine or bone can preserve its original biogenic composition. The aims here are to review the current knowledge surrounding these various isotopic tools, address their potential preservation in biological apatite and provide the palaeobiologist a guide on the different toolkits available and discuss their potential applications in vertebrate palaeobiology with a case study involving two mammal assemblages from the Pleistocene of Europe.
\end{abstract}

Key words: non-traditional isotopes, palaeobiology, calcium, cave bear, Pleistocene.

GEOCHEMICAL tools are a great asset to infer biological characteristics in fossil organisms that otherwise would remain completely unnoticed with morphological 
observations alone. Among stable isotopes, carbon $(\mathrm{C})$, oxygen $(\mathrm{O})$ and nitrogen $(\mathrm{N})$ have been and are still widely used in ecology, archaeology and in palaeoecology. From the vertebrate individual organism to the community, it is possible to reconstruct body temperatures and infer thermophysiology, reconstruct ambient palaeoenvironmental conditions and infer habitat use and migrations; and last but not least to reconstruct diet and trophic structures in ancient food webs. Most isotope approaches rely on stable isotope ratios of carbon and oxygen but also on radiogenic strontium preserved in fossilised tooth and bone. Elemental concentrations have also proved useful in many contexts such as dietary inference. For example, elemental ratios of strontium to calcium or barium to calcium allow reconstructing ecosystem structures.

Contrary to light isotope systems, which have a variability beyond $10 \%$, nontraditional isotopes comprising alkaline earths $(\mathrm{Ca}, \mathrm{Mg})$ or transition metals $(\mathrm{Cu}, \mathrm{Fe}$, $\mathrm{Zn}$ ), show isotope variability within a maximum range of 2-3\%. Recent analytical progresses from the domains of earth sciences now allow the measurement of such stable isotope systems, which show limited fractionation and require high precision and accuracy of measurements from mass spectrometers. The main basis for all those geochemical applications is already starting to be applied to archaeological studies (see review by Jaouen and Pons, 2016). As long as diagenesis can be assessed, there should be no temporal restrictions for their applications to fossil samples. Here, the reader will be presented briefly with traditional systems used in palaeobiology and for further information will refer to previous reviews in ecology and palaeobiology (e.g. Kelly, 1999; Koch, 2007; Newsome et al. 2010). We will then present a summary of the current research on non-traditional isotopes in modern and extinct vertebrates; present the different analytical toolkits available and present new information on a case study using $\mathrm{Ca}$ isotopes.

\section{TRADITIONAL ISOTOPES IN PALAEOBIOLOGY}

New analytical techniques are now being implemented and allow the measurement of non-traditional isotope ratios. Nevertheless, geochemical approaches to investigate the trophic organization of modern vertebrate ecosystems rely primarily on carbon $\left(\delta^{13} \mathrm{C}\right)$, nitrogen $\left(\delta^{15} \mathrm{~N}\right)$ and elemental concentration ratios $(\mathrm{Sr} / \mathrm{Ca}$ and $\mathrm{Ba} / \mathrm{Ca})$. Palaeoenvironmental information can be derived from oxygen $\left(\delta^{18} \mathrm{O}\right)$ and radiogenic strontium $\left({ }^{87} \mathrm{Sr} /{ }^{86} \mathrm{Sr}\right)$ but also sulfur isotopes $\left(\delta^{34} \mathrm{~S}\right)$. Because each element is 
independently affected by diagenesis and because environmental or physiological processes may add some noise to the observed isotopic variability, it is important to explore new systems that will be used in conjunction with traditional methods. Traditional isotope systems are briefly presented below, underlining their use in vertebrate palaeobiology. For comprehensive reviews on traditional systems, the reader may consult among others Gannes et al. (1998), Koch (2007), Newsome et al. (2010), Clementz (2012).

\section{C isotopes}

The observation that carbon radioisotopic dates were systematically younger than expected when analysing plants such as corn led to the recognition of an isotopic difference between plants with different photosynthetic pathways (Bender, 1968). As a consequence, $\delta^{13} \mathrm{C}$ values have been used to address the contribution of $\mathrm{C}_{3}$ versus $\mathrm{C}_{4}$ plants in human and animal diets since at least the late '70s (Vogel, 1978; De Niro and Epstein, 1978; van der Merwe, 1982). Such a discovery had some major implications in palaeobiology and the study of ancient climates and environments with the recognition that $\mathrm{C}_{4}$ plants became predominant in terrestrial ecosystems at the end of the Miocene (Cerling et al. 1997). Although carbon isotopes can be measured in various soft tissues, palaeontological studies focus on mineral tissues such as teeth or bone, where carbon takes part in the carbonate fraction of bioapatite. Therefore, carbon isotopes also permitted to highlight trophic dynamics between mammals and changing environments through deep time (Macfadden et al. 1999) and provide specific clues as to diets of extinct hominins (Schoeninger, 2012). Across aquatic environments, carbon isotopes can also account for productivity with the highest $\delta^{13} \mathrm{C}$ values measured in animal tissues living in upwelling and near-shore marine habitats and the lowest $\delta^{13} \mathrm{C}$ values measured in animals living in marine offshore or estuarine / freshwater habitats (Clementz and Koch, 2001).

\section{Nisotopes}

Nitrogen is a major constituent of proteins and among vertebrate fossil samples, collagen is exclusively retrieved from bone or dentine but not from tooth enamel. Primary producers provide a diversified isotopic baseline to the rest of the food chain 
but among vertebrates, physiological processes induce isotopic fractionation, which is responsible for the strong relation of $\delta^{15} \mathrm{~N}$ with trophic levels. For this reason, nitrogen isotopes are commonly used to discriminate between herbivores and carnivores in ecological studies (De Niro and Epstein, 1981). Other physiological processes related to nitrogen isotope abundances involve nursing and weaning. For example, $\delta^{15} \mathrm{~N}$ time series highlighting transition from mother's milk diet to an adult diet have been monitored on dentinal annuli of sectioned marine mammal teeth (Newsome et al. 2010). In the 1980s, it was demonstrated that collagen could be preserved in recent fossil bones (Armstrong et al. 1993; Stafford et al. 1988) and this discovery opened the way for using $\delta^{15} \mathrm{~N}$ in paleodietary investigations (Ambrose, 1990). However, nitrogen isotopes are rarely preserved beyond 100,000 years (Koch, 2007) hence paleodietary inferences are limited to "recent" fossil faunas.

\section{$O$ isotopes}

Another important stable isotope system is oxygen with the measurement of its isotope abundances in bone apatite $\left(\delta^{18} \mathrm{O}_{\mathrm{p}}\right)$ allowing inferring the source of drinking water (Longinelli, 1984). Such results can be used to calculate mean air temperatures and reconstruct past climatic conditions as was done in Cretaceous continental ecosystems (Amiot et al. 2011). In addition to palaeoenvironmental inferences, this system opened notable perspectives, for example in reconstructing the thermophysiology of long extinct faunas such as dinosaurs (Barrick and Showers, 1994; Amiot et al. 2006) or marine reptiles from the Mesozoic (Bernard et al. 2010). Measuring oxygen isotopes also has demonstrated interest with incremental tissues recording long paleoclimatic records such as in fossil elephant tusks or theropod tooth enamel (Koch et al. 1989; Goedert et al. 2016a).

\section{$S$ isotopes}

Sulfur enters the composition of collagen and sulfur isotopes have been measured in bone from a variety of archaeological contexts allowing discriminating between marine and terrestrial sources (Richards et al. 2001). Because sulfur may substitute to phosphate as sulfate in bioapatite, its investigation in fossil bone and 
teeth offers perspectives of research in the fossil record (Koch, 2007; Goedert et al. 2016b).

\section{NON-TRADITIONAL ISOTOPES IN MODERN FAUNAS}

Bioessential elements are involved in various metabolic processes and have a recognized vital role in the body. Their concentrations are tightly regulated in blood in order to lie between the deficiency and toxicity thresholds (Balter et al. 2013). Despite many caveats (Burton and Price, 2002; Ezzo, 1994), this simple rule has often been forgotten in bone-chemistry studies. As such, the concentration of bioessential elements in fossil bones and teeth can potentially be used for tracking paleodeficiencies or toxicities, at best (Patterson et al. 1987; Rasmussen et al. 2008). In addition, the regulation of a given bioessential element is associated with kinetic processes, changes in the molecular configuration of binding molecules, and redox conditions that are generally associated with isotopic fractionation. This has been recognized early for Ca (Skulan et al. 1997; Skulan and DePaolo, 1999; Heuser and Eisenhauer, 2010) and isotopic fractionation of $\mathrm{Ca}$ remains a promising tool for tracing dietary change from bone and tooth compositions (Reynard et al. 2010; Reynard et al. 2011; Reynard et al. 2013). In this section, however, we will also review the current understanding on fractionation related to biological processes on trace elements (TEs) such as $\mathrm{Mg}, \mathrm{Fe}, \mathrm{Cu}$ and $\mathrm{Zn}$, emphasizing on isotopic ratios rather than solely on concentrations.

\section{Ca isotopes}

Calcium isotopes were initially measured in earth materials in the 1970s (Russell et al. 1978) but the first studies to provide evidence for isotope variation in biological materials, both modern and fossil, are more recent (Skulan et al. 1997; Skulan and DePaolo, 1999). It was first recognized that for a same trophic level, the calcium isotope values for marine organisms were higher than those reported for continental organisms (Skulan et al. 1997). This observation is of importance because it becomes necessary to keep comparisons within well-defined assemblages, the initial source of calcium being environmental and possibly originating from food and/or drinking water. In fact, seawater calcium value was originally found to be enriched in heavy isotopes compared to river water and quite uniform because of the long residence time 
of calcium in the ocean (Zhu and Macdougall, 1998). The second study led to the recognition that trophic levels could be inferred from calcium isotope variability, both in marine and continental assemblages (Skulan and DePaolo, 1999) and later confirmed in a study focusing on modern and fossil marine mammals (Clementz et al. 2003) and more recently on modern and fossil elasmobranchs (Martin et al. 2015a). As for continental environments, Chu et al. (2006) did not find significant calcium isotope variability in relation to geological and environmental conditions and suggested that calcium isotope variability might be largely controlled by diet. Moreover, Chu et al. (2006) reported that milk has a distinctly light isotope composition. In a later report, Reynard et al. (2010) did not recognize any trophic level effect in a continental archaeological assemblage but confirmed a physiological effect related to lactation. Heuser et al. (2011) also suggested calcium isotope fractionation due to physiological differences between mammals, dinosaurs and reptiles. They also suggested minimal diagenetic overprint on calcium isotope values in Mesozoic continental vertebrates. Melin et al. (2014) analysed two modern terrestrial mammalian faunas but did not find significant trophic level effects. However, their study highlighted the necessity to use calcium isotopes in conjunction with other isotope proxys, such as carbon. There is certainly differing physiological effects on calcium isotope fractionation and the recent analyses of different mammal organs challenge previous assumptions on the processes behind calcium isotope fractionation (Tacail et al. 2014). It is to be noted that some organisms such as fish and elasmobranchs do fit in the trophic level effect hypothesis but that marine mammals only partly fit in that picture, with peculiar physiological processes possibly at play (Martin et al. 2015a).

Those preliminary studies have shown encouraging perspectives for reconstructing trophic structures from calcium isotopes preserved in osteological remains of modern vertebrates (see references above). Certainly, more work is needed to understand the physiological aspects behind calcium isotope fractionation, but used in conjunction with other proxies, $\delta^{44} \mathrm{Ca}$ can reveal new palaeobiologcial information. Here, fractionation processes between the diet and the mineralized tissues of a vertebrate takes place at each step of the trophic chain. There is a progressive decrease of calcium isotope ratios from primary producers to higher trophic levels, whether in continental or marine ecosystems. 
High precision measurements of magnesium isotopes are relatively recent thanks to the advent of MC-ICP-MS technology (Galy et al. 2001). As with calcium, magnesium is a bioessential element involved in both plant (Black et al. 2006) and animal metabolism (Nadler and Rude, 1995). Recent analyses in bone and teeth of two African mammalian faunas showed an increase of about $0.25 \%$ of the ${ }^{26} \mathrm{Mg} /{ }^{24} \mathrm{Mg}$ ratio at each step of a trophic chain (Martin et al. 2014). Further analysis in enamel from a mammalian fauna from Gabon has shown a similar ordering according to trophic level although overlap between dietary categories is present. The possible mechanism explaining such isotopic variability is because feces leave the body ${ }^{26} \mathrm{Mg}$ depleted relative to diet, a depletion that is balanced by a ${ }^{26} \mathrm{Mg}$-enriched muscle reservoir (Martin et al. 2015b). Used in conjunction with $\mathrm{Ba} / \mathrm{Ca}$ elemental ratios preserved in enamel, $\delta^{26} \mathrm{Mg}$ highlighted a distinction between herbivores and omnivores (Martin et al. 2015b). Also, a similar correlation was highlighted between $\delta^{26} \mathrm{Mg}$ and $\delta^{66} \mathrm{Zn}$ on the same samples (Jaouen and Pons, 2016). Contrary to calcium, there is a potential effect of the substrate because of the isotopic heterogeneity of geological reservoirs (Martin et al. 2014). Hence, there is a necessity to analyze faunas from a same provenance. This isotope approach is only recently explored and necessitates the establishment of a large database in modern ecosystems. Conversely in the fossil record, no data have been published yet but when possible other geochemical proxys such as radiogenic strontium, if not modified during diagenesis, should be checked to monitor substrate homogeneity. Furthermore, physiological processes responsible for magnesium isotope fractionation have not been explored yet and spatial variability at the scale of tooth, dentition and body reservoirs remain to be looked at in details. There are also open perspectives for studying magnesium isotope variability in marine ecosystems with $\mathrm{Mg}$ being highly concentrated in seawater, it is suspected that, as for marine $\mathrm{Ca}$, homogeneity in the primary source of $\mathrm{Mg}$ might provide a clear reading of trophic level effects. Research perspectives are therefore high both for physiology, ecology and palaeobiology.

\section{$\mathrm{Cu}, \mathrm{Fe}$ and $\mathrm{Zn}$ isotopes}


Transition metals including copper $(\mathrm{Cu})$, iron $(\mathrm{Fe})$ and zinc $(\mathrm{Zn})$ show isotope variability in vertebrate soft tissues that encompasses isotope variability observed in earth materials (Balter et al. 2010; Walczyk and von Blanckenburg, 2005; Jaouen et al. 2013). Those elements play essential metabolic roles and have the potential to trace physiological processes. Of relevance to palaeontological questions is the record of such fractionation processes in bioapatite, which could be preserved in fossils. Iron and copper isotope variability in male versus female blood is different (Walczyk and von Blanckenburg, 2005; Jaouen et al. 2012) and the fractionation process behind it could be menstruations (Jaouen and Balter, 2014). Jaouen et al. (2012) found that such isotopic difference is also documented in archaeological bones. Although an inventory of such fractionation processes in modern mammal blood and bone has yet to be conducted, interesting perspectives for sex determination of our ancient relatives can be thought of. Potentially, inference on sex ratios in community structure or sexual dimorphism in the fossil record could be pinpointed.

Zinc isotopes seem to be of relevance for ecological studies, particularly at inferring trophic levels as recently demonstrated in continental (Jaouen et al. 2013; 2016a) and coastal (Jaouen et al. 2016b) mammal faunas, although some overlap between dietary categories also exists. As for magnesium isotopes, it is suspected that the substrate also influences the heterogeneity of the results (Jaouen et al. 2016a). Nevertheless, in the study involving marine mammals (Jaouen et al. 2016b), the use of $\delta^{13} \mathrm{C}$ and $\delta^{15} \mathrm{~N}$ highlight a correlation between nitrogen and zinc isotopes. Also, a similar patterning, i.e. an increase of the $\delta^{66} \mathrm{Zn}$ ratio up trophic chain, is recorded in both bone and enamel (Jaouen et al. 2016a), which offers interesting applications to the fossil record.

\section{Sr isotopes}

Strontium incorporated in animal tissue is derived from food and drinking water. Radiogenic ${ }^{87} \mathrm{Sr}$ is a decay product of ${ }^{87} \mathrm{Rb}$, which is highly variable from one geological substrate to another. Hence, the ${ }^{87} \mathrm{Sr} /{ }^{86} \mathrm{Sr}$ ratio measured in animal tissues mirrors that of the local geological substrate and many studies, especially in archaeology, use this ratio to explore mobility of past human populations; for a comprehensive review the reader is directed to Bentley (2006). Radiogenic strontium can also be used in palaeontology to discuss the mobility and habitat of Mesozoic 
vertebrates (Kocsis et al. 2009; Martin et al. 2016) or to reconstruct palaeoenvironments of even older faunas such as elasmobranchs of the Permian and Triassic (Fischer et al. 2012; 2013).

From a palaeodietary perspective, mass-dependent stable strontium isotope composition has recently received attention with $\delta^{88 / 86} \mathrm{Sr}$ (involving the ${ }^{88} \mathrm{Sr} /{ }^{86} \mathrm{Sr}$ ratio) showing a decrease from herbivores to carnivores, thus bearing important information for diet reconstruction in archaeology (Knudson et al. 2010) and potentially also in palaeontology. Variations of the ${ }^{88} \mathrm{Sr} /{ }^{86} \mathrm{Sr}$ ratio can be measured both with thermal ionization (Krabbenhöft et al. 2009) and multicollector ICP-MS (Knudson et al. 2010).

\section{FROM THE SAMPLE TO THE ISOTOPE RATIO}

In comparison to light stable isotopes, non-traditional ones are heavier and show smaller isotope fractionation in the range of a few per mils. For these reasons, assessing the variability of alkaline earth metals such as $\mathrm{Ca}$ (expressed as $\delta^{44} \mathrm{Ca}$ ), $\mathrm{Mg}$ $\left(\delta^{26} \mathrm{Mg}\right)$ and transitions metals such as $\mathrm{Cu}\left(\delta^{65} \mathrm{Cu}\right), \mathrm{Fe}\left(\delta^{56} \mathrm{Fe}\right), \mathrm{Zn}\left(\delta^{66} \mathrm{Zn}\right)$ is relatively new in the domain of earth sciences, thanks to significant instrument improvements (e.g. Albarède and Beard, 2004). The different steps from sampling to analyzing such non-traditional isotopes in biogenic apatite are summarized in Figure 1.

The quantity needed for analysis is dependent 1) on the concentration of the element of interest into the sample material (i.e. bone or tooth) and 2) on the limits of detection of the mass spectrometer. Both $\mathrm{Ca}$ and $\mathrm{Mg}$ are considered major constituents of bioapatite making up to nearly $40 \mathrm{wt} \%$ and several thousands of ppm respectively. $\mathrm{Fe}$ and $\mathrm{Zn}$ make between 20 and $100 \mathrm{ppm}$ while $\mathrm{Cu}$ is the least concentrated of all, present at about $10 \mathrm{ppm}$ levels. Isotope ratios are measured on two types of mass spectrometers, either TIMS for $\mathrm{Ca}$ and Fe or ICP-MS for $\mathrm{Ca}, \mathrm{Mg}, \mathrm{Cu}$, $\mathrm{Fe}, \mathrm{Zn}$. One measurement on MC-ICP-MS requires about $2 \mu \mathrm{g}$ of $\mathrm{Ca}$ and less than $0.4 \mu \mathrm{g}$ of $\mathrm{Mg}, \mathrm{Cu}, \mathrm{Fe}$ and $\mathrm{Zn}$. Therefore, considering both elemental concentrations in the sample and the amenable measure, the needed weight for a sample remains small for $\mathrm{Ca}$ and $\mathrm{Mg}$ (about 1 milligrams will provide 100 measures of $\mathrm{Ca}$ and between 10 and 50 measures of $\mathrm{Mg}$ ) but is relatively larger for $\mathrm{Cu}, \mathrm{Fe}$ and $\mathrm{Zn}$ (40 milligrams of bioapatite is needed for 1 measure of $\mathrm{Cu}$ and 10 measures of $\mathrm{Fe}$ and $\mathrm{Zn}$ ) (Table 1 shows two examples, the first is barely destructive to the sample and corresponds to 
the minimal weight allowing to comfortably measure $\mathrm{Ca}$ and $\mathrm{Mg}$ isotope ratios. In the second case, the weight needed is more destructive and corresponds to a typical uptake necessary to conduct $\delta^{15} \mathrm{~N}$ analysis of bone collagen. This last choice now allows measuring isotope ratios of $\mathrm{Cu}, \mathrm{Fe}$ and $\mathrm{Zn}$ ). The advantage of calcium is its high concentration in bioapatite, which allows minimal quantities of sample to be taken. Using a computer-assisted microdrill, it is possible to obtain the desired weight by leaving holes about $350 \mu \mathrm{m}$ in diameter. This is particularly interesting when asking permission to sample curated specimens. Moreover, this leaves plenty of space for spatial sampling along accreting tissues, for example across incremental annuli in teeth or otoliths recording mineralization during the life of an animal. At this stage, it is possible to either directly place the samples in Teflon beakers and dissolve them in nitric or hydrochloric acid, or to add a step to remove potential diagenetic carbonates and other associated allochtonous elements through leaching.

Following sampling and dissolution, bone or teeth are subjected to chemical purification in the clean laboratory using acids and ion exchange resins in order to remove the phosphate matrix and any other elements that could potentially lead to destabilizations or interferences in the isotopic measurements. Strontium is present in variable concentration in vertebrate apatite (Peek and Clementz, 2011) and needs to be removed. Because both doubly charged strontium and single charged calcium have so close mass to charge ratios $(\mathrm{m} / \mathrm{z})$ for main measured isotopes $\left({ }^{84} \mathrm{Sr}^{++},{ }^{86} \mathrm{Sr}^{++}\right.$and ${ }^{88} \mathrm{Sr}^{++}$interfering with ${ }^{42} \mathrm{Ca}^{+},{ }^{43} \mathrm{Ca}^{+}$and ${ }^{44} \mathrm{Ca}^{+}$respectively), the $\mathrm{Sr}$ has to be removed from sample to avoid interferences with calcium during analysis. Here, the goal is to retrieve the element of interest in a separate vial and depending on the protocol, all other elements composing bioapatite may be discarded or kept in separate vials for further chemical purification. At this stage, it is very important to collect close to 100 $\%$ of the element (referred as yields); else incomplete collection will cause the sample to become fractionated from its original isotope composition, thus leading to skewed results (Russell and Papanastassiou 1978). Complete collection of a given element is first implemented using elution profiles of standard samples. Each element composing the sample travels with different kinematics through the resin depending on the molarity of the acid used. When the right recipe is established, the element is collected at the end of the column in a Teflon beaker. Details about elution profiles and resin chromatography of vertebrate mineralized tissues are described in the literature for calcium (Tacail et al. 2014; Martin et al. 2015a), for magnesium (Martin 
et al. 2014; 2015b) and for copper, iron and zinc (Balter et al. 2010). Yields can be assessed by measuring the presence/absence of signals in split solution collected before and after the expected elution of the targeted element. At the end of the purification step, collected volumes containing the purified element are dried down on a hot plate. Once completely dried, the sample can be retaken in a fixed volume corresponding to the expected concentration for subsequent analysis on the mass spectrometer. According to the instrument of choice, the sample is either kept liquid (MC-ICP-MS) or completely re-dried (TIMS).

Originally, non-traditional isotopic systems were measured on Thermal Ionization Mass Spectrometers (TIMS). Isotopic measurements of $\mathrm{Ca}, \mathrm{Mg}, \mathrm{Cu}, \mathrm{Fe}$ and $\mathrm{Zn}$ can now be achieved on Multi-Collector Inductively Coupled Plasma Mass Spectrometers (MC-ICPMS), the analytical details and guidelines of which are explained in Albarède et al. (2004). Both types of spectrometers differ in the introduction method of the sample, but their geometry remains comparable. In TIMS, a drop of the liquid sample is dried on a filament composed of a neutral element such as rhenium or tungsten, which undergoes heating into vacuum. The solid sample eventually becomes ionized and gets accelerated into the mass spectrometer. As for MC-ICP-MS, the sample is diluted in a low concentrated acid (often $0.05 \mathrm{~N} \mathrm{HNO}_{3}$ ), gets nebulized into a carrier gas, in this case Ar, and is eventually ionized into an argon plasma. At this stage, the sample enters a vacuum space and becomes accelerated into the mass spectrometer. Because plasma-ionized particles have high energy spread, it is necessary to focus the ion beam with an electrostatic analyzer (ESA), which sets the kinetic energy of the ion beam within a narrower energy spread. The beam then proceeds through a magnetic sector, which separates ions according to their mass to charge ratios $(\mathrm{m} / \mathrm{z})$. The different isotopes then hit the detector, which is constituted of several faraday cups (hence the name multi-collector) that turn the different ion beams into measurable voltages. Based on the different voltages, isotope ratios are then calculated. This combination of an ESA and a magnetic sector is known as a double focusing geometry, allowing for a better transmission and mass resolution. The TIMS instrument does not need a double focusing geometry because the ion beam provided by thermal ionization has a limited energy spread thanks to the ionization setup method. Therefore, ions are only sorted according to their masses using a magnetic sector. 
Laser ablation systems consist in flash-firing a high-energy laser beam onto the sample surface, resulting in a nearly bulk vaporization of solid sample. These setups can now be connected to the MC-ICP-MS. The advantage of this method is that no chemistry is undertaken, allowing for a direct spatial analysis of samples. It is important to remember that flat surfaces are necessary for such analyses and therefore this requires cutting and/or polishing samples, which is obviously destructive and unfeasible for precious specimens. The major drawback remains analytical because ablating a sample implies ionizing a wide variety of elements in the plasma, therefore creating a wealth of interferences that need to be corrected. Calcium isotopes can be measured in this way provided a strict matrix-matching method together with a thorough correction of $\mathrm{Sr}$ interferences ( $\mathrm{Li}$ et al. 2015; Tacail et al. 2016) and analytical implementation for laser ablation of $\mathrm{Mg}, \mathrm{Cu}, \mathrm{Fe}$ and $\mathrm{Zn}$ isotope ratios in bioapatite is pending.

Isotope fractionation effects in alkaline earths and transition metals are small; in other words, isotope abundance ratios, which can be measured with high precision, show relatively small variation in nature. As raw isotope ratios are difficult to deal with and are pointless as such, we report normalised deviations from a reference material. Moreover, because variations of isotope compositions are small, we multiply it by a magnifying factor, typically 1000 . This is all expressed in a single equation, which applies to any traditional or non-traditional isotopic system:

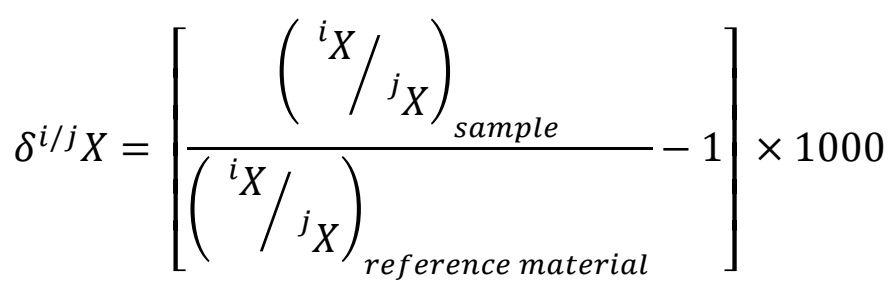

where ${ }^{i} X$ and ${ }^{j} X$ stand for molar abundances of isotopes $i$ and $j$ of element $X$ respectively and the $\delta$ value is expressed in \%o units. For magnesium, the delta notation is given by $\delta^{\mathrm{x}} \mathrm{Mg}=\left[\left({ }^{\mathrm{x}} \mathrm{Mg} /{ }^{24} \mathrm{Mg}\right)_{\text {sample }} /\left({ }^{\mathrm{x}} \mathrm{Mg} /{ }^{24} \mathrm{Mg}\right)_{\text {reference }}-1\right] \cdot 10^{3}$ where $\mathrm{x}=26$ or 25, and the DSM3 solution for the standard. For copper, the delta notation is given by $\delta^{65} \mathrm{Cu}=\left[\left({ }^{65} \mathrm{Cu} /{ }^{63} \mathrm{Cu}\right)_{\text {sample }} /\left({ }^{65} \mathrm{Cu} /{ }^{63} \mathrm{Cu}\right)_{\text {reference }}-1\right] .10^{3}$ with the NIST-SRM976 solution for the standard. For iron, the delta notation is given by $\left.\delta^{\mathrm{x}} \mathrm{Fe}=\left[\left({ }^{\mathrm{x}} \mathrm{Fe} /{ }^{54} \mathrm{Fe}\right)_{\text {sample }} /\left({ }^{\mathrm{x}} \mathrm{Fe} /{ }^{54} \mathrm{Fe}\right)\right)_{\text {reference }}-1\right] \cdot 10^{3}$ where $\mathrm{x}=56$ or 57 , and the IRMM14 solution for the standard. For zinc, the delta notation is given by $\delta^{\mathrm{x}} \mathrm{Zn}=\left[\left({ }^{\mathrm{x}} \mathrm{Zn} /{ }^{64} \mathrm{Zn}\right)_{\text {sample }} /\left({ }^{\mathrm{x}} \mathrm{Zn} /{ }^{64} \mathrm{Zn}\right)_{\text {reference }}-1\right] \cdot 10^{3}$ where $\mathrm{x}=66,67$ or 68 , and the JMC3- 
0749 Lyon for the standard. Different notations are used for Ca where the full isotopic ratio is commonly given in the exponent to express whether ${ }^{40} \mathrm{Ca}$ has been measured or not.

\section{DIAGENESIS OF NON-TRADITIONAL ISOTOPES}

Recognizing isotope systems as tracers of biological processes in modern skeletal tissues provides interesting perspectives for their applications in the fossil record. However, delving into the past implies the risk that any original biogenic signal could be overprinted or replaced during diagenesis and the least to be done is to control for its effects. Post mortem modifications of the original chemical composition can be challenging to assess when interpreting isotopic compositions of fossil samples. The intensity of diagenesis depends on the concentration ratio between the diagenetic fluid and the fossil, i.e. the water/rock (W/R) ratio, and the difference of the isotopic composition between the diagenetic fluid and the fossil. Departures from original isotopic composition have been modeled using simple mass balance for $\mathrm{Mg}, \mathrm{Ca}, \mathrm{Fe}$, $\mathrm{Cu}$ and $\mathrm{Zn}$ isotopes, for the continental and marine settings (Fig. 2). The developed model does not involve classical W/R equations, as given in Sharp (2007) for example, because it does not take into account the initial and final stages of bioapatite alteration. It neither takes into account isotopic fractionation between fluid and bioapatite, which have been otherwise not determined. The equation reads:

$$
\delta M_{\text {mix }}=\frac{x M_{b i o} * \delta M_{b i o} *[M]_{b i o}+(1-x) M_{d i a} * \delta M_{d i a} *[M]_{d i a}}{x M_{b i o} *[M]_{b i o}+(1-x) M_{d i a} *[M]_{d i a}}
$$

where $M$ stands for the metal, $\delta M$ and $[M]$ its isotope composition and concentration, respectively, the subscripts bio and dia for biological and diagenetic fraction, respectively, and $x$ the fraction of altered bioapatite. Departure from original isotopic composition is given by the ratio $\delta M_{m i x} / \delta M_{b i o}$ for a given value of $x$. Four consequences emerge from these calculations. The first is that mixing of diagenetic $\mathrm{Mg}$ and $\mathrm{Ca}$ in the terrestrial setting is unlikely because the $\mathrm{Mg}$ and Ca concentrations in rivers are negligible relative to those in bioapatite. Second, the mixing of diagenetic $\mathrm{Mg}$ in the marine setting is probably very important because the $\mathrm{Mg}$ concentration in seawater is similar to that of bioapatite. Third, the diagenesis of transition metals (Fe, 
$\mathrm{Cu}$ and $\mathrm{Zn}$ ) in the terrestrial environment is likely to be an efficient process because their concentrations are lower in bioapatite than in rivers. And fourth, the diagenesis of transition metals in the marine environment is probably unlikely because their concentrations in seawater are under the ppb level, while they are 1000 times higher in bioapatite.

Despite the fact that the $\mathrm{Ca}$ isotopic composition of bone and tooth is hardly modifiable by diagenesis, there is a risk that the measured $\mathrm{Ca}$ and $\mathrm{Mg}$ isotope composition is overprinted due to the presence of secondary calcite in the porosity of the samples. As a rule, the fossil bone and teeth have to be rid of secondary carbonates, and more generally of any secondary mineral phase. This step (leaching) is achieved using diluted acetic acid $(0.1 \mathrm{M})$, that will dissolve secondary carbonates, leaving bioapatite, which will be finally dissolved using more concentrated nitric acid $(\sim 30 \%)$. It exists many leaching procedures and the reader will find some useful references describing the different protocols in Balter et al. (2002a). Transition metals, such as $\mathrm{Fe}, \mathrm{Cu}$ and $\mathrm{Zn}$ can be associated with oxyhydroxids that need to get dissolved using reducing agents such as hydroxylamine.

Once calcite and oxyhydroxides have been leached from the fossil bone or enamel samples, it is necessary to proceed to post-hoc tests to check whether the concentrations and the isotope compositions are related or not and whether the measured elements are derived from a diagenetic or a biogenic pool. Tests of diagenesis on trace elements and their isotopes have recently been reviewed in Reynard and Balter (2014). Tests of diagenesis will have to be constantly implemented. As such, if a sizable pool of a biological metal $M$ is exchanged with a diagenetic component, this would affect the $M$ isotopic composition and concentration and the samples would fall on a $1 / M$ versus $\delta M$ line representing the mixing between the biological and the diagenetic $M$ components. This simple scheme holds if the biological and diagenetic pools are different enough in terms of isotopic composition and concentration to generate a single $1 / M$ versus $\delta M$ mixing line. However, if we emphasize that the diagenetic pool would be quite homogeneous in terms of isotopic composition and concentration, the biological pool can be easily characterized by an important variability. This will generate as many mixing lines as it exists of original isotopic compositions, leading to an overall blurred $1 / M$ versus $\delta M$ relationship. 
Anyway, such controls are necessary to ensure we provide isotopic values related to biological fractionation and not diagenesis.

The study of diagenetic influence on the isotope composition of calcium in fossil bone and teeth has not received a lot of attention. This is also the case for magnesium and zinc, which have only been recently recognised to bear some trophic level information in modern samples. Heuser et al. (2011) have conducted some tests and discussed the effects of diagenesis on calcium isotopes in phosphatic tissues. They measured similar $\mathrm{Ca}$ isotope values for fossil bone, dentine and their surrounding sediment $(n=5)$ either implying exchange between sediment and skeletal tissue or addition of calcium to the tissue in the form of newly formed minerals. Heuser et al. (2011) also emitted the hypothesis that Ca isotope composition could reflect that of the local substrate during the lifetime of the animal.

Other methods exist to control for the diagenetic alteration of bone. For example, it will be necessary to monitor the concentration of phosphorous and calcium. Under stoichiometric condition the ratio $\mathrm{Ca} / \mathrm{P}$ is close to $2.2 \mathrm{in}$ modern biological apatite (bone or teeth) (Sillen, 1986). Nevertheless, that one element is affected by diagenesis does not necessarily means that others will be.

\section{LATE PLEISTOCENE CASE STUDY WITH Ca ISOTOPES}

In order to test for the preservation of biogenic information from calcium isotopes, we measured two faunal assemblages of late Pleistocene age. The importance of analysing a relatively "recent" fossil fauna is that dietary behaviour can be approximated with a certain level of confidence and our new calcium results can be compared with other geochemical proxies of the literature to test for consistencies in palaeobiological interpretations. In this particular case, bone preserves collagen so calcium isotopes can be compared with nitrogen isotopes derived from the same samples. Moreover, enamel lacks collagen but trace elements such as strontium and barium are less prone to alteration and their elemental concentrations can be compared to calcium isotopes derived from the same samples.

Two Late Pleistocene mammal assemblages recovered from cave deposits

were compared for their isotope variability in $\delta^{44 / 42} \mathrm{Ca}$. The specimens from Scladina cave, Sclayn, Belgium originate from layer $1 \mathrm{~A}$, dated $>36.2 \mathrm{kyr}$ and $38.7 \pm 1.5 \mathrm{kyr} \mathrm{BP}$ (Gilot, 1992). The specimens from Jaurens, Corrèze, France originate from a single 
cave dated from 29.7 to $32.6 \mathrm{kyr}$ BP (Guerin et al. 1979). The fauna from Sclayn is the same as analysed in previous studies for C, N (Bocherens et al. 1997) and for $\mathrm{Sr} / \mathrm{Ca}$ and $\mathrm{Ba} / \mathrm{Ca}$ elemental ratios (Balter et al. 2001, 2002b). The fauna from Jaurens was selected for this study in the collections of Université Lyon 1.

\section{Material and analytical methods}

The Sclayn assemblage contains 17 specimens all consisting of bone powder representing 7 species: 3 Bison priscus, 2 Crocuta crocuta, 2 Equus caballus, 1 Mammuthus primigenius, 2 Coelodonta antiquitatis, 1 Ursus arctos and 6 Ursus spelaeus. The Jaurens assemblage contains 27 enamel specimens and 1 bone specimen (Fig. 3, Figs. S3, S4). The enamel-bone pair belongs to a single species, Panthera pardus, but whether it belongs to a single individual cannot be assessed. Species sampled for tooth enamel include 3 Bison priscus, 3 Coelodonta antiquitatis, 3 Rangifer tarandus, 3 Canis lupus, 5 Crocuta crocuta, 4 Panthera spelaea and 4 Ursus arctos. About $300 \mu \mathrm{g}$ of tooth enamel was sampled with a computer-assisted microdrill (New wave Research) under a binocular (Olympus SZ61).

Calcium from fossil samples was purified using a two-step chemical process involving Sr-specific resin followed by a cation-exchange resin (Tacail et al. 2014). The purified calcium fraction of each sample was measured for isotope ratios on a Neptune Plus MC-ICP-MS at Laboratoire de Géologie de Lyon (e.g. Martin et al. 2015 for details). Delta values were obtained using the standard-sample bracketing method with ICP Ca Lyon as standard (Tacail et al. 2014). As MC-ICP-MS technique does not allow the measurement of ${ }^{40} \mathrm{Ca}$ due to interference from ${ }^{40} \mathrm{Ar}$ plasma, isotopic compositions are expressed as delta values calculated using the ${ }^{44} \mathrm{Ca} /{ }^{42} \mathrm{Ca}$ isotopic ratio as follows:

$$
\delta^{44 / 42} \mathrm{Ca}=\left[\frac{\left({ }^{44} \mathrm{Ca} /{ }^{42} \mathrm{Ca}\right)_{\text {sample }}}{\left({ }^{44} \mathrm{Ca} /{ }^{42} \mathrm{Ca}\right)_{\text {ICP Ca Lyon }}}-1\right] \times 1000
$$

We report four independent measurements of NIST standard SRM1486 (average = $1.01 \%$, see Table S2 for details) that are in good agreement with previously 
published values $(-1.04 \pm 0.11 \%$, 2SD in Martin et al. 2015; $-1.03 \pm 0.13 \%$, 2SD in Tacail et al. 2016). Long-term reproducibility as measured for SRM1486 is $0.12 \%$. When plotted against $\delta^{44 / 42} \mathrm{Ca}, \delta^{43 / 42} \mathrm{Ca}$ values fall on a line with null $\mathrm{y}$-axis origin and a slope of $0.487 \pm 0.022$ (2SE) (Fig. S1). Variations of isotope compositions depend thus on mass of isotopes, respecting the mass-dependent fractionation of isotopes that predicts a slope of about 0.5 .

Leaching experiments were conducted on two samples from Jaurens to assess their isotope values (Table S2). For each sample, bone or tooth powder was selected, then divided into two batches. The first batch was treated as such with no pretreatment. The second batch was pretreated using $0.1 \mathrm{~N}$ ultrapure acetic acid to leach carbonates or any diagenetic pollutants from the sample for 30 minutes. This sample was rinsed three times using MQ water and the remaining sample was ran through the same purification technique and analytical procedure as the untreated sample.

Results

In the Sclayn assemblage, calcium isotope values (Table S2, Fig. 4) range from -0.86 to $-1.39 \%$, which is significantly higher than the observed range of values in the Jaurens assemblage from -1.14 to $-2.02 \%$ (Wilcoxon-Mann-Whitney, $\mathrm{p}=$ 0.00000077). The lowest values of the Sclayn dataset are represented by Crocuta crocuta and Mammuthus primigenius. In the Jaurens dataset, the lowest values are represented by the Crocuta and the P. pardus enamel sample. In both datasets, higher values are represented by Coelodonta antiquitatis, Equus caballus, Bison priscus and Ursus arctos and Ursus spelaeus. Intermediate values are represented by Rangifer tarandus, Canis lupus and Panthera spelaea in the Jaurens sample. The value for the calcite encrusting a tooth of Crocuta crocuta (FSL300610) is the highest of the dataset $(-0.28 \% \pm 0.05,2 \mathrm{SD}, \mathrm{n}=3)$.

The results of the leaching experiment show a slight difference between calcium isotope values obtained for the bone sample (FSL 301081) with the untreated bone sample showing a slightly higher value $(-1.38 \% \pm 0.11,2 \mathrm{SD})$ than the leached sampled $(-1.52 \% \pm 0.03,2 \mathrm{SD})$. The leached enamel sample (FSL 3009181ea) 
compares well with the untreated enamel sample (FSL 300918) with values of -1.48 $\%$ $\pm 0.04,2 \mathrm{SD}$ versus $-1.45 \% \pm 0.06,2 \mathrm{D}$, respectively.

Concentration analyses for $\mathrm{Ca}, \mathrm{P}, \mathrm{Mg}, \mathrm{Sr}, \mathrm{Ba}$ and $\mathrm{Zn}$ are recorded alongside $\mathrm{Ca}$ isotope values in Table $\mathrm{S} 2$. $\mathrm{Ca} / \mathrm{P}$ ratios for the Jaurens samples average $1.98 \pm 0.13$ 2SD.

Are Ca isotope values of biogenic nature?

The range of $\mathrm{Ca} / \mathrm{P}$ ratios measured in tooth enamel samples from Jaurens and the bone samples from Sclayn respect the stoichiometry of bioapatite $(2.02 \pm 0.09$ 2SD) and the values are within the range of expected values for modern bone (Sillen, 1986) as well as for the bone standard SRM1486 measured in the same analytical session (1.95). Such results indicate that if any changes occurred during diagenesis, they affected equally calcium and phosphorous. Here, the average calcium and phosphorous concentrations in tooth enamel are $33.3 \% \pm 4.4$ and $16.3 \% \pm 4.0$ (1SD), respectively. The average calcium and phosphorous concentrations in bones from Sclayn are much lower being $13.4 \pm 3.5 \%$ and $6.4 \pm 1.7 \%$ (1SD) respectively, indicating important diagenetic-related leaching of these elements. As a comparison, in the modern bone standard SRM1486, the values are of $44.9 \%$ and $23.0 \%$. The leaching experiment conducted here (Table S2) on one enamel sample shows that both calcium and phosphorous have been leached away preserving stoichiometry $([\mathrm{Ca}]=20.4 \%,[\mathrm{P}]=10.8 \%$ for the leached sample $(\mathrm{FSL} 3009181 \mathrm{ea}),[\mathrm{Ca}]=31.8 \%$, $[\mathrm{P}]=15.9 \%$ for the untreated sample (FSL 300918)). In the case of the bone leached here (FSL 300918lea), almost no Ca and P were lost, possibly due to the fact that collagen or other material in the porous structure makes it less soluble. Although the evidence is indirect, these results show that leaching may have been responsible for the observed lower concentrations of calcium and phosphorous into the fossil bones than in fossil tooth enamel samples.

Although stoichiometry is preserved, does leaching have an impact on measured calcium isotope composition? The measured $\delta^{44 / 42} \mathrm{Ca}$ difference may not be significant given the larger error obtained on the untreated sample that falls within the range of the leached sample. Nevertheless, it could also be compatible with a small diagenetic overprint in bone from secondary calcite. Indeed, the calcite sample has a ${ }^{44} \mathrm{Ca}$-enriched calcium isotope composition and diagenetic contamination of 
secondary calcite in the pores of fossil bone would tend to lead to heavier isotope compositions. The second sample, which consists of tooth enamel shows both values obtained on untreated and treated samples as undistinguishable $(-1.45 \% \pm 0.06,2 \mathrm{SD}$ vs $-1.48 \% \pm 0.04,2 \mathrm{SD}$, respectively). We do not observe significant effects of the leaching process on calcium isotope values, although more analyses should be undertaken to confirm this.

Conversely, uptake of diagenetic calcium cannot be confirmed here. One way to look at such diagenetic inclusion is to search for correlations between elements that are absent during the lifetime of an animal and that eventually enter bioapatite during fossilization. Here, we observe no correlation between $\delta^{44 / 42} \mathrm{Ca}$ and manganese concentration, which was obviously added into bioapatite after the death of the animal (Fig. S2). Manganese is virtually absent from modern bone as indicated here with SRM1486 with 4 ppm measurable. Manganese is incorporated during fossilization as is often visible in fossils with the characteristic manganese dendrites. Unsurprisingly here, fossil bone is more concentrated in manganese $(>600 \mathrm{ppm})$ than are tooth enamel samples (average $=70 \mathrm{ppm}$ ). Other elemental concentrations such as rare earth elements (REE), Uranium or Thorium diagenetic uptakes could not be measured here because the sampled masses were too low to pass detection limits. It is to be noted that other elements used in ecological studies $(\mathrm{Sr}, \mathrm{Ba}, \mathrm{Zn}, \mathrm{Mg}$ ) were measured for concentration and are within the range of observed values in modern samples (see Table S2).

Further preservation of an original biogenic calcium isotope value is supported by the calcium isotope values that are significantly different from the value measured on the calcite surrounding fossil specimens. The value of calcite $(-0.28 \% \pm 0.05)$ is within the range of expected values for carbonates (e.g. Fantle and Tipper, 2014). Given the prominence of secondary calcite surrounding fossil samples in the Jaurens deposit, diagenetic overprinting of calcium isotope values would require a shift of isotope values from fossil samples toward higher values and beyond the range of expected values for modern samples. The fact that mammal tooth or bone values are within the range of values measured in previous studies for modern bone and teeth (Skulan et al. 1999; Clementz et al. 2003; Reynard et al. 2010; Tacail et al. 2014; Martin et al. 2015) suggests that the $\delta^{44 / 42} \mathrm{Ca}$ values recorded in both fossil assemblages reflect a strong biogenic component. 
The spread is nearly double in Jaurens $(0.88 \%$ ) than in Scalyn $(0.53 \%$ ) and it could be argued that bone samples are diagenetically altered toward higher isotope values reflecting that of the substrate. Nevertheless, the observed scatter in calcium isotope values corresponds to the isotope variability recorded in the bone of modern terrestrial mammals, both in modern and archaeological context and are most likely representing biogenic characteristics (Reynard et al. 2010; Tacail et al. 2014). Whether this is related to dietary or physiological effects is discussed below.

\section{Palaeocological inferences}

The analysis of two datasets of similar ages and faunal compositions but of different tissues, the assemblage from Sclayn consisting of bone and the one from Jaurens consisting of tooth enamel; provides some new insights on calcium isotope variability in some recently extinct mammal species. The two localities share three broad ecological categories including herbivores with $C$. antiquitatis and B. priscus, omnivores with $U$. arctos and carnivores with $C$. crocuta. The first observation is a systematic difference with higher mean values for bone than for tooth enamel with a $\Delta_{\text {enamel-bone }}$ of $-0.39 \%$ for C. antiquitatis, of $-0.34 \%$ for B. priscus, of $0.07 \%$ for $U$. arctos and of $-0.60 \%$ for C. crocuta. This offset is of $-0.47 \%$ if all values are averaged per assemblage ( $-1.06 \%$ for bone versus $-1.53 \%$ for tooth enamel). This

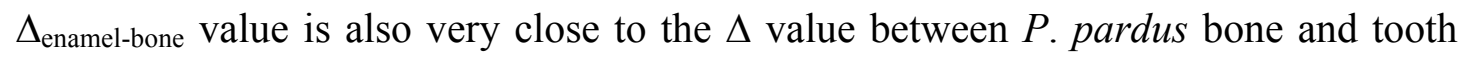
enamel within the single assemblage at Jaurens ( $-0.54 \%$ ). Previously published offsets are smaller. Heuser et al. (2011) found a smaller offset between dentine and tooth enamel of about $-0.20 \%$ for dinosaur and Tacail et al. (2014) reported an offset of $-0.30 \%$ between bone and tooth enamel for sheep. Martin et al. (2015) reported a positive offset between bone and tooth enamel of $+0.20 \%$ in marine mammals. The enamel-bone spacing observed in the present study provides support that original biogenic information has been retained. Indeed, a better understanding of the fractionation processes between different mineralized tissues requires systematic pairs within a same individual. Given the different residence times of calcium in bone, enamel or dentine reservoirs, further skeletal variability will have to be explored and will have to consider that the variety of bone tissues may also reflect further isotopic differences. Most important here for the purpose of faunal comparison is to keep in 
mind that bone and tooth enamel calcium isotope values cannot be readily compared. Comparing fossil assemblages should focus on single tissue analyses.

The present environmental context is continental and although initial studies recognized a trophic ordering of calcium isotopes values in continental ecosystems (Skulan and DePaolo, 1997; Skulan et al. 1999), a more recent study found that this might be less straightforward (Melin et al. 2014). That a trophic level effect has been recognized in the marine environment appears settled, although the offset between trophic levels is not large (Skulan et al. 1999; Clementz et al. 2003; Martin et al. 2015). Reasons for this limited trophic level effect have been discussed in the light of seawater as a buffering medium but this study also found that marine mammals do not fully fit in this picture (Martin et al. 2015). Clearly, physiological aspects need to be explored to fully understand its impact, together with diet on the observed values. Here, whether for the bone or tooth enamel dataset, calcium isotope values show low dispersion by taxonomic group. To the exception of mammoths and reindeers, all herbivores possess the highest values in the dataset. Carnivores have systematically lower values although this is less significant for Panthera spelaea and Canis lupus, which show some overlap with the Bison group. Ingestion of mineralized tissue such as bone in the diet of Crocuta crocuta agrees with the interpretation that a diet composed of mineralized tissues, such as that of Tyrannosaurus rex, could explain the low isotope values (Heuser et al. 2011). But the present low isotope values recovered for $P$. pardus, which is not known to specifically feed on bone, remains puzzling. This requires further datapoints, as admittedly here, only two samples of $P$. pardus were available for analysis. An obvious outlier is represented by Rangifer tarandus, which presents values in the range of the carnivore group. Given that second molars sampled for $R$. tarandus may form early, a nursing effect may be suspected with a milk-based diet potentially explaining the low values (see Chu et al. 2006) observed here.

Comparing our calcium isotope data with other geochemical proxies of interest in ecology provides additional insights on the mechanisms behind calcium isotope fractionation. First of all, nitrogen isotopes extracted from bone collagen allow for trophic inferences and the present dataset from Sclayn provides an opportunity to compare $\delta^{15} \mathrm{~N}$ values from the same samples analysed for calcium isotopes. The two Crocuta crocuta samples, representing the only carnivores of the dataset are clearly separated from other mammals with the highest $\delta^{15} \mathrm{~N}$ and lowest $\delta^{44 / 42} \mathrm{Ca}$ values, which would provide a sound argument for a dietary imprint of 
calcium isotopes (Fig. 5A). Interestingly, the single mammoth datapoint also falls within the range of values for Crocuta crocuta. Previous studies based on nitrogen isotopes have underlined the discrepancy between mammoth $\delta^{15} \mathrm{~N}$ values and those of other herbivores highlighting that the mammoth fed on highly ${ }^{15} \mathrm{~N}$-enriched plants (Schwartz-Narbonne et al. 2015) or practicing coprophagy (Clementz et al. 2009; van Geel et al. 2015) making it isotopically looking like a carnivore. The present calcium isotope values could also be linked to specific plant consumption and although more datapoints are needed to confirm this, it is known that $\delta^{44 / 42} \mathrm{Ca}$ is variable in plants, including across different organs (see compilation in Fantle and Tipper, 2014). Comparing the $\mathrm{Sr} / \mathrm{Ca}$ ratios with $\delta^{44 / 42} \mathrm{Ca}$ values in the Jaurens sample reveals an ordering that follows the biopurification of strontium (Balter, 2004) (see Fig. 5B). Here, Crocuta crocuta and Panthera pardus are the most biopurified samples, which could be interpreted as taxa occupying the highest trophic position in the ecosystem. This pattern follows their lowest calcium isotope values in the Jaurens dataset and for this reason, it is tempting to interpret calcium isotope data as a proxy for trophic level. Here, in the $\mathrm{Sr} / \mathrm{Ca}$ versus $\delta^{44 / 42} \mathrm{Ca}$ space, other apex carnivores such as wolves and lions do overlap with bisons and reindeers, which implies that other factors are at play in the isotope fractionation of calcium. However, rhinoceroses are closely located in a putative herbivore space. Further work is needed to decipher the role of different food sources, seasonality or physiological effects such as milking or weaning on the record of calcium isotopes in tooth enamel. In contrast to marine ecosystems, the source of $\mathrm{Ca}$ in continental environments is probably extremely diverse for vertebrate organisms (e.g. variability in a single plant from roots to leaves) and could explain the large variability and overlap observed here.

As demonstrated above, used in conjunction with other proxies, calcium isotopes can provide some insights on the diet of extinct taxa. Relevant to our assemblage is the inferred diet of Ursus arctos and Ursus spelaeus, which remains a matter of debate (e.g. Robu et al. 2013) although recent studies have underlined mostly plant-based consumption for U. spelaeus (e.g. Krajcarz et al. 2016). Although at Sclayn, $U$. arctos is represented by a single individual in our dataset, we do not find a significant difference between its calcium isotope value and those of $U$. spelaeus.

The Jaurens tooth enamel dataset where $\mathrm{Sr} / \mathrm{Ca}$ and $\delta^{44 / 42} \mathrm{Ca}$ values are plotted show that $U$. arctos falls in mid-range values together with bisons, reindeers and part of the wolves and lions (Fig. 5). If we consider those values to represent trophic 
levels, then it could be interpreted that $U$. arctos from Jaurens were omnivorous or herbivorous in agreement with modern observations (Robu et al. 2013). As for the Sclayn bone dataset, $U$. spelaeus also falls with other herbivores within the $\delta^{15} \mathrm{~N}$ versus $\delta^{44 / 42} \mathrm{Ca}$ space. The sole $U$. arctos datapoint is positioned slightly outside the herbivore group in what could correspond to the omnivore group but admittedly, a single datapoint is not enough here to draw conclusions on its dietary habits and also because the carnivores are clearly underrepresented. The absence of a clear calcium isotope difference between $U$. arctos and U. spelaeus is preliminary here and it should be stressed out that such comparison involves two assemblages of different locations and slightly different ages as well as comparing enamel versus bone datasets. Also, as discussed above, it cannot be ruled out that diet is not the only factor on calcium isotope fractionation and deciphering dietary versus physiological influence on calcium isotope fractionation requires some extensive research efforts. Several studies based on nitrogen isotopes from bone collagen conclude to a herbivorous status for $U$. spelaeus (Krajcarz et al. 2016). Moreover, similar studies from a single locality recover $U$. spelaeus with significantly lower $\delta^{15} \mathrm{~N}$ values relative to $U$. arctos, implying a distinct herbivorous versus an omnivorous diet for these two taxa (Bocherens et al. 2011). Nevertheless, omnivory for U. spelaeus has been proposed on the basis of nitrogen and carbon isotopes (Richards et al. 2008; Robu et al. 2013) and on the basis of microwear (Peigné et al. 2009). Dietary heterogeneity at the scale of the population but also in relation to season is to be expected and opens perspectives of research notably with the help of other proxies, including the geochemical proxies presented in this work.

\section{CONCLUSIONS}

Traditional isotope approaches to vertebrate palaeobiology offered and are still offering major insights into the ecology and evolution of extinct faunas. Important information on palaeoenvironments, resource use and physiology can be derived from oxygen, carbon, and sufur isotopes. Indeed, the major limitation on paleodietary inference is linked to the preservation of collagen, which is a prerequisite for the measurement of nitrogen isotopes. On the other hand, preservation potential of nontraditional isotopes seems high in biomineralised tissues. Moreover, fractionation appears to be controlled by physiological processes and there is increasing evidence 
that some of these non-traditional isotope systems (e.g. $\mathrm{Mg}, \mathrm{Ca}, \mathrm{Zn}$ ) may represent useful paleodietary tracers. The palaeoecogical inferences drawn from calcium isotopes are still in their infancy and among the subjects to be addressed, there remains variability linked to physiology and diet. Calcium offers interesting perspectives because it requires only a small quantity of sample (less than half a milligram) and therefore allows for the development of precise time series and the study of seasonal variations at the scale of tissue increments. Moreover, where collagen has completely degraded, calcium (and perhaps magnesium) will furnish promising aspects on future research due to their relatively high concentrations and preservation potentials in mineralized tissues.

Acknowledgments. We thank Andrew Smith for inviting us to contribute to this special issue derived from the Palass annual symposium in Lyon. JEM thanks Emmanuel Robert for allowing the microsampling of fossil specimens from Jaurens curated in the palaeontological collections of Université Lyon 1. Two anonymous reviewers provided insightful comments that helped improve the final version of this work. Consumables used in the clean lab for this study were partly paid for by JEM's DIUNIS project (TelluS INSU 2017 - action INTERRVIE).

\section{REFERENCES}

ALBAREDE, F. and BEARD, B. 2004. Analytical methods for non-traditional isotopes. Reviews in Mineralogy and Geochemistry 55, 113-152.

ALBAREDE, F., TELOUK, P., BLICHERT-TOFT, J., BOYET, M., AGRANIER, A. and NELSON, B. 2004. Precise and accurate isotopic measurements using multiplecollector ICPMS. Geochimica et Cosmochimica Acta 68, 2725-2744.

AMBROSE, S.H. 1990. Preparation and characterization of bone and tooth collagen for isotopic analysis. Journal of Archaeological Science 17, 431-451.

AMIOT, R., LECUYER, C., BUFFETAUT, E., ESCARGUEL, G., FLUTEAU, F. and MARTINEAU, F. 2006. Oxygen isotopes from biogenic apatites suggest widespread endothermy in Cretaceous dinosaurs. Earth and Planetary Science Letters 246, 41-54. 
AMIOT, R., WANG, X., ZHOU, Z., WANG, X., BUFFETAUT, E., LECUYER, C., DING, Z., FLUTEAU, F., HIBINO, T., KUSUHASHI, N., MO, J., SUTEETHORN, V., WANG, Y., XU, X. and ZHANG, F. 2011. Oxygen isotopes of East Asian dinosaurs reveal exceptionally cold Early Cretaceous climates. Proceedings of the National Academy of Sciences 108, 5179-5183.

ARMSTRONG, W.G., HALSTEAD, L.B., REED, F.B. and WOOD, L. 1983. Fossil proteins in vertebrate calcified tissues. Philosophical Transactions of the Royal Society B 301, 301-343.

BAlter, V., PERSON, A., LABOURDETTE, N., DRUCKER, D., RENARD, M., VANDERMEERSCH, B. 2001. Were Neandertalians essentially carnivores? Sr and $\mathrm{Ba}$ preliminary results of the mammalian palaeobiocoenosis of Saint-Césaire. Comptes Rendus à l'Académie des Sciences IIA 332, 59-65.

BALTER V., SALIEGE J.F., BOCHERENS H., PERSON A. 2002a. Evidences of physico-chemical and isotopic modifications in archaeological bones during controlled acid etching. Archaeometry 44, 329-336.

BALTER, V., BOCHERENS, H., PERSON, A., LABOURDETTE, N., RENARD, M. and VANDERMEERSCH, B. 2002b. Ecological and physiological variability of $\mathrm{Sr} / \mathrm{Ca}$ and $\mathrm{Ba} / \mathrm{Ca}$ in mammals of West European mid-Würmian food webs. Palaeogeography, Palaeoclimatology, Palaeoecology 186, 127-143.

BALTER, V. 2004. Allometric constraints on $\mathrm{Sr} / \mathrm{Ca}$ and $\mathrm{Ba} / \mathrm{Ca}$ partitioning in terrestrial mammalian trophic chains. Oecologia 139, 83-88.

BALTER, V., ZAZZO, A., MOLONEY, A.P., MOYNIER, F., SCHMIDT, O., MONAHAN, F.J. and ALBAREDE, F. 2010. Bodily variability of zinc natural isotope abundances in sheep. Rapid Communications in Mass Spectrometry 24, 605612. 
BALTER, V., LAMBOUX, A., ZAZZO, A., TELOUK, P., LEVERRIER, Y., MARVEL, J., MOLONEY, A.P., MONAHAN, F.J., SCHMIDT, O., ALBAREDE, F. 2013. Contrasting $\mathrm{Fe}, \mathrm{Cu}$, and $\mathrm{Zn}$ isotopic patterns in organs and body fluids of mice and sheep, with emphasis on cellular fractionation. Metallomics 5, 1470-1482.

BARRICK, R.E. and SHOWERS, W.J. 1994. Thermophysiology of Tyrannosaurus rex: evidence from oxygen isotopes. Science $\mathbf{2 6 5}, 222-224$.

BENDER, M.M. 1968. Mass spectrometric studies of carbon 13 variations in corn and other grasses. Radiocarbon 10, 468-472.

BENTLEY, R.A. 2006. Strontium isotopes from the earth to the archaeological skeleton: a review. Journal of Archaeological Method and Theory 13, 135-187.

BERNARD, A., LECUYER, C., VINCENT, P., AMIOT, R., BARDET, N., BUFFETAUT, E., CUNY, G., FOUREL, F., MARTINEAU, F., MAZIN, J-M., and PRIEUR, A. 2010. Regulation of body temperature by some Mesozoic marine reptiles. Science 328, 1379-1382.

BLACK, J.R., YIN, Q. and CASEY, W.H. 2006. An experimental study of magnesium-isotope fractionation in chlorophyll-a photosynthesis. Geochimica et Cosmochimica Acta 70, 4072-4079.

BOCHERENS, H., BILIOU, D., PATOU-MATHIS, M., BONJEAN, D., OTTE, M. and MARIOTTI, A. 1997. Palaeobiological implications of the isotopic signatures $\left({ }^{13} \mathrm{C},{ }^{15} \mathrm{~N}\right)$ of fossil mammals collagen in Scladina Cave (Sclayn, Belgium). Quaternary Research 48, 370-380.

BOCHERENS, H., STILlER, M., HOBSON, K.A., PACHER, M., RABEDER, G., BURNS, J.A., TÜTKEN, T. and HOFREITER, M. 2011. Niche partitioning between two sympatric genetically distinct cave bears (Ursus spelaeus and Ursus ingressus) and brown bear (Ursus arctos) from Austria: isotopic evidence from fossil bones. Quaternary International 245, 238-248. 
BURTON, J.H., and PRICE, T.D. 2000. The use and abuse of trace elements for paleodietary research. Chapter 8 pp. 159-171 in Biogeochemical approaches to paleodietary analysis (Ambrose and Katzenberg, eds). Kluwer Academic/Plenum Publishers New York.

CERLING, T.E., HARRIS, J.M., MACFADDEN, B.J., LEAKEY, M.G., QUADE, J., EISENMANN, V. and EHLERINGER, J.R. 1997. Global vegetation change through the Miocene/Pliocene boundary. Nature 389, 153-158.

CLEMENTZ, M.T., HOLDEN, P. and KOCH, P.L. 2003. Are calcium isotopes a reliable monitor of trophic level in marine settings? International Journal of Osteoarchaeology 13, 29-36.

CLEMENTZ, M.T. and KOCH, P.L. 2001. Differentiating aquatic mammal habitat and foraging ecology with stable isotopes in tooth enamel. Oecologia 129, 461-472.

CLEMENTZ, M.T., FOX-DOBBS, K., WHEATLEY, P.V., KOCH, P.L. and DOAK, D.F. 2009. Revisiting old bones: coupled carbon isotope analysis of bioapatite and collagen as an ecological and palaeoecological tool. Geological Journal 44, 605-620.

CLEMENTZ, M.T. 2012. New insight from old bones: stable isotope analysis of fossil mammals. Journal of Mammalogy 93, 368-380.

CHU, N-C., HENDERSON, G.M., BELSHAW, N.S. and HEDGES, R.E.M. 2006. Establishing the potential of $\mathrm{Ca}$ isotopes as proxy for consumption of dairy products. Applied Geochemistry 21, 1656-1667.

DE NIRO, M.J. and EPSTEIN, S. 1978. Influence of diet on the distribution of carbon isotopes in animals. Geochimica et Cosmochimica Acta 42, 495-506.

DE NIRO, M.J. and EPSTEIN, S. 1981. Influence of diet on the distribution of nitrogen isotopes in animals. Geochimica et Cosmochimica Acta 45, 341-351. 
EZZO, J.A. 1994. Putting the "chemistry" back into archaeological bone chemistry analysis: modelling potential paleodietary indicators. Journal of Anthropological Archaeology 13, 1-34.

FANTLE, M.S. and TIPPER, E.T. 2014. Calcium isotopes in the global biogeochemical Ca cycle: implications for development of a Ca isotope proxy. EarthScience Reviews 129, 148-177.

FISCHER, J., SCHNEIDER, J.W., HODNETT, J-P., ELLIOTT, D.K., JOHNSON, G.D., VOIGT, S., JOACHIMSKI, M.M., TICHOMIROWA, M. and GÖTZE, J. 2013. Stable and radiogenic isotope analyses on shark teeth from the Early to the Middle Permian (Sakmarian-Roadian) of the southwestern USA. Historical Biology 26, 710 727.

FISCHER, J., VOIGT, S., FRANZ, M., SCHNEIDER, J.W., JOACHIMSKI, M.M., TICHOMIROWA, M., GÖTZE, J. and FURRER, H. 2012. Palaeoenvironments of the late Triassic Rhaetian Sea: implications from oxygen and strontium isotopes of hybodont shark teeth. Palaeogeography, Palaeoclimatology, Palaeoecology 353-355, $60-72$.

GALY, A., BELSHAW, N.S., HALICZ, L. and O’NIONS, R.K. 2001. High-precision measurement of magnesium isotopes by multiple-collector inductively coupled plasma mass spectrometry. International Journal of Mass Spectrometry 208, 89-98.

GANNES, L.Z., MARTÍNEZ DEL RIO, C. and KOCH, P. 1998. Natural abundance variations in stable isotopes and their potential uses in animal physiological ecology. Comparative Biochemistry and Physiology-Part A 119, 725-737. 
van GEEL, B., GUTHRIE, R.D., ALtMANN, J.G., BROEKENS, P., BULl, I.D., GILL, F.L., JANSEN, B., NIEMAN, A.M. and GRAVENDEEL, B. 2011. Mycological evidence of coprophagy from the feces of an Alakan Late Glacial mammoth. Quaternary Science Reviews 30, 2289-2303.

GILOT, E. 1992. Sclayn: datation par ${ }^{14} \mathrm{C}$ du Moustérien final. In: Recherches aux grottes de Sclayn, Vol. 1, Le Contexte. Etudes et Recherches Archéologiques de l'Université de Liège 27, 173.

GOEDERT, J., AMIOT, R., BOUDAD, L., BUFFETAUT, E., FOUREL, F., GODEFROIT, P., KUSUHASHI, N., SUTEETHORN, V., TONG, H., WATABE, M. and LECUYER, C. 2016a. Preliminary investigation of seasonal patterns recorded in the oxygen isotope composition of theropod dinosaur tooth enamel. Palaios 31, 10 19.

GOEDERT, J., FOUREL, F., AMIOT, R., SIMON, L. and LECUYER, C. 2016 b. High-precision 34S/32S measurements in vertebrate bioapatites using purge-and-trap elemental analyser/isotope ratio mass spectrometry technology. Rapid Communications in Mass Spectrometry 30, 2002-2008.

GUERIN, C., PHILIPPE, M. and VILAIN, R. 1979. Le gisement Pleistocène supérieur de la grotte de Jaurens à Nespouls, Corrèze, France: historique et généralités. Nouvelles Archives du Muséum d'Histoire naturelle de Lyon 17, 11-16.

HEUSER, A., and EISENHAUER, A. 2010. A pilot study on the use of natural calcium isotope $\left({ }^{44} \mathrm{Ca} /{ }^{40} \mathrm{Ca}\right)$ fractionation in urine as a proxy for the human body calcium balance. Bone 46, 889-896.

HEUSER, A., TÜTKEN, T., GUSSONE, N. and GALER, S. J. G. 2011. Calcium isotopes in fossil bones and teeth - Diagenetic versus biogenic origin. Geochimica and Cosmochimica Acta, 75, 3419-3433. 
JAOUEN, K., BALTER, V., HERRSCHER, E., LAMBOUX, A., TELOUK, P. and ALBAREDE, F. 2012. Fe and $\mathrm{Cu}$ stable isotopes in archaeological human bones and their relationship to sex. American Journal of Physical Anthropology 148, 334-340.

JAOUEN, K., PONS, M-L. and BALTER, V. 2013. Iron, copper and zinc isotopic fractionation up mammal trophic chains. Earth and Planetary Science Letters 374, $164-172$.

JAOUEN, K. and BALTER, V. 2014. Menopause effect on blood Fe and $\mathrm{Cu}$ isotope compositions. American Journal of Physical Anthropology 153, 280-285.

JAOUEN, K. and PONS, M.L. 2016. Potential of non-traditional isotope studies for bioarchaeology. Archaeological and Anthropological Sciences doi:10.1007/s12520016-0426-9.

JAOUEN, K., BEASLEY, M., SCHOENINGER, M., HUBLIN, J-J. and RICHARDS, M.P. 2016a. Zinc isotope ratios of bones and teeth as new dietary indicators: results from a modern food web (Koobi Fora, Kenya). Scientific Reports 6, 26281.

JAOUEN, K., SZPAK, P. and RICHARDS, M.P. 2016b. Zinc isotope ratios as indicators of diet and trophic level in Arctic marine mammals. PLOS ONE 11, e0152299.

KELLY, J.F. 1999. Stable isotopes of carbon and nitrogen in the study of avian and mammalian trophic ecology. Canadian Journal of Zoology 78, 1-27.

KNUDSON, K., WILLIAMS, H.M., BUIKSTRA, J.E., TOMCZAK, P.D., GORDON, G.W., ANBAR, A.D. 2010. Introducing $\delta^{88 / 86} \mathrm{Sr}$ analysis in archaeology: a demonstration of the utility of strontium isotope fractionation in paleodietary studies. Journal of Archaeological Science 37, 2352-2364.

KOCH, P., FISCHER, D.C. and DETTMAN, D. 1989. Oxygen isotope variation in the tusks of extinct proboscideans: a measure of season of death and seasonality. Geology 17, 515-519. 
KOCH, P. 2007. Isotopic study of the biology of modern and fossil vertebrates. In: Michener, R. and Lajtha, K. (eds). Stable isotopes in ecology and environmental science. $2^{\text {nd }}$ edition. Blackwell Publishing, Boston, MA. pp. 99-154.

KOCSIS, L., ÖSI, A., VENNEMANN, T., TRUEMAN, C.N. and PALMER, M.R. 2009. Geochemical study of vertebrate fossils from the Upper Cretaceous (Santonian) Csehbánya Formation (Hungary): Evidence for a freshwater habitat of mosasaurs and pycnodont fish. Palaeogeography, Palaeoclimatology, Palaeoecology 280, 532-542.

KRABBENHÖFT, A., FIETZKE, J., EISENHAUER, A., LIEBETRAU, V., BÖHM, F. and VOLLSTAEDT, H. 2009. Determination of radiogenic and stable strontium isotope ratios $\left({ }^{87} \mathrm{Sr} /{ }^{86} \mathrm{Sr} ; \delta^{88} /{ }^{86} \mathrm{Sr}\right)$ by thermal ionization mass spectrometry applying an ${ }^{87} \mathrm{Sr} /{ }^{84} \mathrm{Sr}$ double spike. Journal of Analytical Atomic Spectrometry 24, 1267-1271.

KRAJCARZ, M., PACHER, M., KRAJKARZ, M.T., LAUGHLAN, L., RABEDER, G., SABOL, M., WOJTAL, P. and BOCHERENS, H. 2016. Isotopic variability of cave bears $\left(\delta^{15} \mathrm{~N}, \delta^{13} \mathrm{C}\right)$ across Europe during MIS 3. Quaternary Science Reviews $131,51-72$.

LI, Q., THIRLWALL, M. and MÜLLER, W. 2016. Ca isotopic analysis of laser-cut microsamples of (bio)apatite without chemical purification. Chemical Geology 422, $1-12$.

LONGINELLI, A. 1984. Oxygen isotopes in mammal bone phosphate: a new tool for paleohydrological and paleoclimatological research? Geochimica and Cosmochimica Acta 48, 385-390.

MACFADDEN, B.J., SOLOUNIAS, N. and CERLING, T.E. 1999. Ancient diets, ecology, and extinction of 5-million-year-old horses from Florida. Science 283, 824 827. 
MARTIN, J.E., VANCE, D. and BALTER, V. 2014. Natural variation of magnesium isotopes in mammal bones and teeth from two South African trophic chains. Geochimica and Cosmochimica Acta 130, 12-20.

MARTIN, J.E., TACAIL, T., ADNET, S., GIRARD, C. and BALTER, V. $2015 \mathrm{a}$. Calcium isotopes reveal the trophic position of extant and fossil elasmobranchs. Chemical Geology 415, 118-125.

MARTIN, J.E., VANCE, D. and BALTER, V. 2015b. Magnesium stable isotope ecology using mammal tooth enamel. Proceedings of the National Academy of Sciences 112, 430-435.

MARTIN, J.E., DEESRI, U., LIARD, R., WATTANAPITUKSAKUL, A., LAUPRASERT, K., TONG, H., BUFFETAUT, E., SUTEETHORN, V., SUAN, G., TELOUK, P. and BALTER, V. 2016. Strontium isotopes reveal long-term residence of thalattosuchians in the freshwater environment. Paleobiology 42, 142-156.

MELIN, A.D., CROWley, B.E., BROWN, S.T., WHEATlEY, P.V., MORITZ, G.L., YU, F.T.Y., BERNARD, H., DEPAOLO, D.J., JACOBSON, A.D. and DOMINY, N.J. 2014. Calcium and carbon stable isotope ratios as paleodietary indicators. American Journal of Physical Anthropology 154, 633-643.

NADLER, J.L. and RUDE, R.K. 1995. Disorders of magnesium metabolism. Endocrinology and Metabolism Clinics of North America 24, 623-641.

NEWSOME, S.D., CLEMENTZ, M.T. and KOCH, P. 2010. Using stable isotope biogeochemistry to study marine mammal ecology. Marine mammal science 26, 509572.

PATTERSON, C.C., SHIRAHATA, H., and ERICSON, J.E. 1987. Lead in ancient human bones and its relevance to historical developments of social problems with lead. The Science of the Total Environment 61, 167-200. 
PEIGNÉ, S., GOILlOT, C., GERMONPRÉ, M., BLONDEL, C., BIGNON, O. and MERCERON, G. 2009. Predormancy diet of the European cave bear: evidence for omnivory from a dental microwear analysis of Late Pleistocene Ursus spelaeus from Goyet, Belgium. Proceedings of the National Academy of Science 106, 15390-15393.

PEEK, S. and CLEMENTZ, M.T. Sr/Ca and $\mathrm{Ba} / \mathrm{Ca}$ variations in environmental and biological sources: a survey of marine and terrestrial systems. Geochimica and Cosmochimica Acta, 95, 36-52.

RASMUSSEN, K.L., BOLDSEN, J.L., KRISTENSEN, H.K., SKYTTE, L., HANSEN, K.L., MØLhOLM, L., GROOTES, P.M., NADEAU, M-J., and ERIKSEN, K.M.F. 2008. Mercury levels in Danish Medieval human bones. Journal of Archaeological Science 35, 2295-2306.

REYNARD, L.M., HENDERSON, G.M. and HEDGES, R.E.M. 2010. Calcium isotope ratios in animal and human bone. Geochimica and Cosmochimica Acta 74, $3735-3750$.

REYNARD, L., HENDERSON, G. M. and HEDGES, R. E. M. 2011. Calcium isotopes in archaeological bones and their relationship to dairy consumption. Journal of Archaeological Science 38, 657-664.

REYNARD, L., PEARSON, J. A., HENDERSON, G. M. and HEDGES, R. E. M. 2013. Calcium isotopes in juvenile milk-consumers. Archaeometry 55, 946-957.

REYNARD, B. and BALTER, V. 2014. Trace elements and their isotopes in bones and teeth: diet, environments, diagenesis, and dating of archeological and paleontological samples. Palaeogeography, Palaeoclimatology, Palaeoecology 416, $4-16$.

RICHARDS, M.P., FULLER, B.T. and HEDGES, R.E.M. 2001. Sulphur isotopic variation in ancient bone collagen from Europe: implications for human palaeodiet, residence mobility, and modern pollutant studies. Earth and Planetary Science Letters 191, 185-190. 
RICHARDS, M.P., PACHER, M., STILLER, M., QUILÈS, J., HOFREITER, M., CONSTANTIN, S., ZILHÃO, J. and TRINKAUS, E. 2008. Isotopic evidence for omnivory among European cave bears: Late Pleistocene Ursus spelaeus from the Peştera cu Oase, Romania. Proceedings of the National Academy of Science 105, $600-604$.

ROBU, M., FORTIN, J.K., RICHARDS, M.P., SCHWARTZ, C.C., WYNN, J.G., ROBBINS, C.T. and TRINKAUS, E. 2013. Isotopic evidence for dietary flexibility among European Late Pleistocene cave bears (Ursus spelaeus). Canadian Journal of Zoology 91, 227-234.

RUSSELL, W.A., PAPANASTASSIOU, D.A. and TOMBRELLO, T.A. 1978. Calcium isotope fractionation in earth and other solar system materials. Geochimica and Cosmochimica Acta 42, 1075-1090.

RUSSELL, W.A. and PAPANASTASSIOU D.A. 1978. Calcium isotope fractionation in ion-exchange chromatography. Analytical Chemistry. 50, 48-51.

SCHOENINGER, M.J. 2012. The ancestral dinner table. Nature 487, 42-43.

SCHWARTZ-NARBONNE， R., LONGSTAFFE, F.J., METCALFE, J.Z. and ZAZULA, G. 2015. Solving the wooly mammoth conundrum: amino acid ${ }^{15} \mathrm{~N}$ enrichment suggests a distinct forage or habitat. Scientific Reports 5, 09791.

SHARP, Z. 2007. Principles of stable isotope geochemistry. Pearson, Prentice Hall $344 \mathrm{p}$.

SILLEN, A. 1986. Biogenic and diagenetic Sr/Ca in Plio-Pleistocene fossils of the Omo Shungura Formation. Paleobiology 12, 311-323.

SKULAN, J., DEPAOLO, D.J. and OWENS, T.L. 1997. Biological control of calcium isotopic abundances in the global calcium cycle. Geochimica and Cosmochimica Acta 61, 2505-2510. 
SKULAN, J. and DEPAOLO, D.J. 1999. Calcium isotope fractionation between soft and mineralized tissues as a monitor of calcium use in vertebrates. Proceedings of the National Academy of Sciences 96, 13709-13713.

STAFFORD, T.W., BRENDEL, K. and DUHAMEL, R. 1988. Radiocarbon, 13C and $15 \mathrm{~N}$ analysis of fossil bone: removal of humates with XAD-2 resin. Geochimica and Cosmochimica Acta 52, 2257-2267.

TACAIL, T., AlBAlAT, E., TELOUK, P. and BALTER, V. 2014. A simplified protocol for measurement of Ca isotopes in biological samples. Journal of Analytical and Atomic Spectrometry 29, 529-535.

TACAIL, T., TELOUK, P. and BALTER, V. 2016. Precise analysis of calcium stable isotope variations in biological apatites using laser ablation MC-ICPMS. Journal of Analytical and Atomic Spectrometry 31, 152-162.

VAN DER MERWE, N.J. 1982. Carbon isotopes, photosynthesis, and archaeology. American Scientist 70, 596-606.

VOGEL, J.C. 1978. Isotopic assessment of the dietary habits of ungulates. South African Journal of Science 74, 298-301.

WALCZYK, T. and VAN BLANCKENBURG, F. 2005. Deciphering the iron isotope message of the human body. International Journal of Mass Spectrometry 242, 117 134.

ZHU, P. and MACDOUGALL, J.D. 1998. Calcium isotopes in the marine environment and the oceanic calcium cycle. Geochimica and Cosmochimica Acta 62 , 1691-1698.

FIGURE CAPTIONS 
FIG. 1. Illustration of the various steps from fossil sampling to isotope ratio mass spectrometry. A, sampling a few milligrams of fossil apatite using a drill bit mounted on a microdrilling device or a dremel tool; B, sample digestion with acid in a Teflon beaker; $\mathrm{C}$, the dissolved sample is subjected to ion-exchange chromatography in order to be purified for an element of interest such as $\mathrm{Ca}, \mathrm{Mg}, \mathrm{Cu}, \mathrm{Fe}$ or $\mathrm{Zn}$; D, MC-ICPMS analysis consists in ionizing the purified sample into a plasma; the different elements will be accelerated into a vacuum and will pass through an electrostatic analyzer that focuses ions according to their kinetic energy, then through a magnetic sector that will sort the isotopes according to their ion mass / ion charge ratios $(\mathrm{m} / \mathrm{z})$; E, Data acquisition and processing. Each mass will hit a different detector, which will convert isotopic abundance into a measurable voltage, allowing calculation of isotope ratios and delta values.

FIG. 2. Departure from the original isotope composition (\%) as a function of the water/rock ratio (W/R, \%), which is assumed to be representative of the fraction of altered bioapatite. In this simple mass balance, no assumption is made concerning diffusion processes. Values used for the calculation are given in supplementary table 4.

FIG. 3. Ursus arctos molar from Jaurens, France sampled in this study. The top picture is before sampling. The arrow in the bottom picture shows the microdrill perforation after sampling highlighting that a minimal amount of sample is needed for calcium isotope measurements. Scale bar represents $1 \mathrm{~cm}$.

FIG. 4. Fossil mammal $\delta^{44 / 42} \mathrm{Ca}$ (in \%o relative to ICP Ca Lyon standard) variability in two Late Pleistocene assemblages. A, the Sclayn (Belgium) dataset exclusively includes bone samples whereas B, the Jaurens (France) dataset includes mostly enamel samples as well as a single bone sample. To the exception of the felids, all silhouettes are taken from www.phylopic.org (Public Domain licence).

FIG. 5. Fossil mammal $\delta^{44 / 42} \mathrm{Ca}$ (in \%o relative to ICP Ca Lyon standard) variability in two Late Pleistocene assemblages A, plotted against $\delta^{15} \mathrm{~N}\left(\%\right.$ atmospheric $\mathrm{N}_{2}$ ) for the bone dataset of Sclayn (Belgium) (Bocherens et al., 1997; Balter et al., 2002b) and B, plotted against $\log (\mathrm{Sr} / \mathrm{Ca})$ for the enamel dataset of Jaurens. 
Table 1. Indicative concentrations of $\mathrm{Ca}, \mathrm{Mg}, \mathrm{Cu}, \mathrm{Fe}$ and $\mathrm{Zn}$ in bioapatite and the quantity of bioapatite needed for one isotopic measurement on MC-ICP-MS.

\section{SUPPLEMENTARY DATA}

Fig. S1. Triple isotope plot $\left(\delta^{44 / 42} \mathrm{Ca}\right.$ versus $\delta^{43 / 42} \mathrm{Ca}$ in \%o $)$ of all data analysed in this study. Regression line is $\mathrm{Y}=0.487( \pm 0.022) \mathrm{X}-0.024( \pm 0.030)$ with $\mathrm{R}^{2}=0.974$. This is in agreement with mass dependent fractionation slope of 0.507 according to exponential law.

Fig. S2. Manganese plotted against $\delta^{44 / 42} \mathrm{Ca}$ values for bone and enamel samples measured in this study.

Fig. S3. Plate with all samples from Jaurens analysed in this study. For each sample, a picture before and after sampling is presented.

Fig. S4. Same as SuppFig.3 for the rest of the samples from Jaurens.

Table S1. Data from the literature used in the model of the water/rock ratio presented in Fig. 3.

Table S2. Calcium isotope values (expressed as $\delta^{44 / 42} \mathrm{Ca}$ and $\delta^{43 / 42} \mathrm{Ca}$ (in \%o) relative to standard ICP Ca-Lyon) measured on two Pleistocene assemblages as well as elemental concentrations for some major and trace elements. (1) $\delta^{13} \mathrm{C}$ and $\delta^{15} \mathrm{~N}$ values from Bochoerens et al. 1997. Tooth type: capital letters refer to the upper tooth row. 
A.

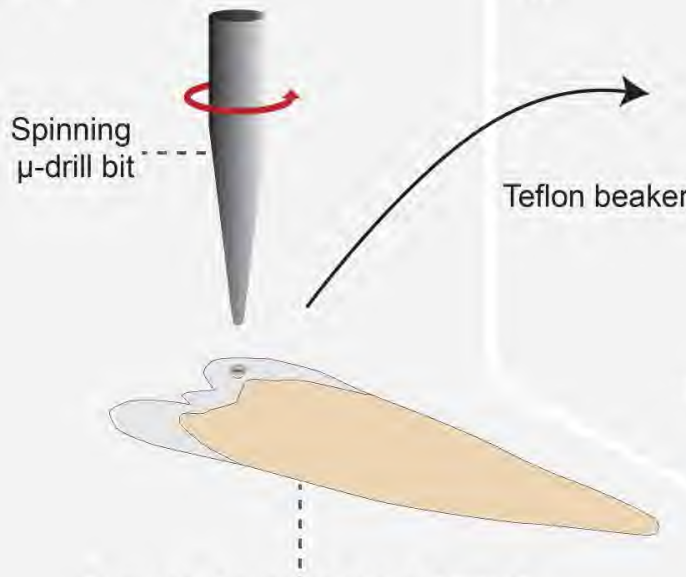

Enamel, dentine or bone sample

D.

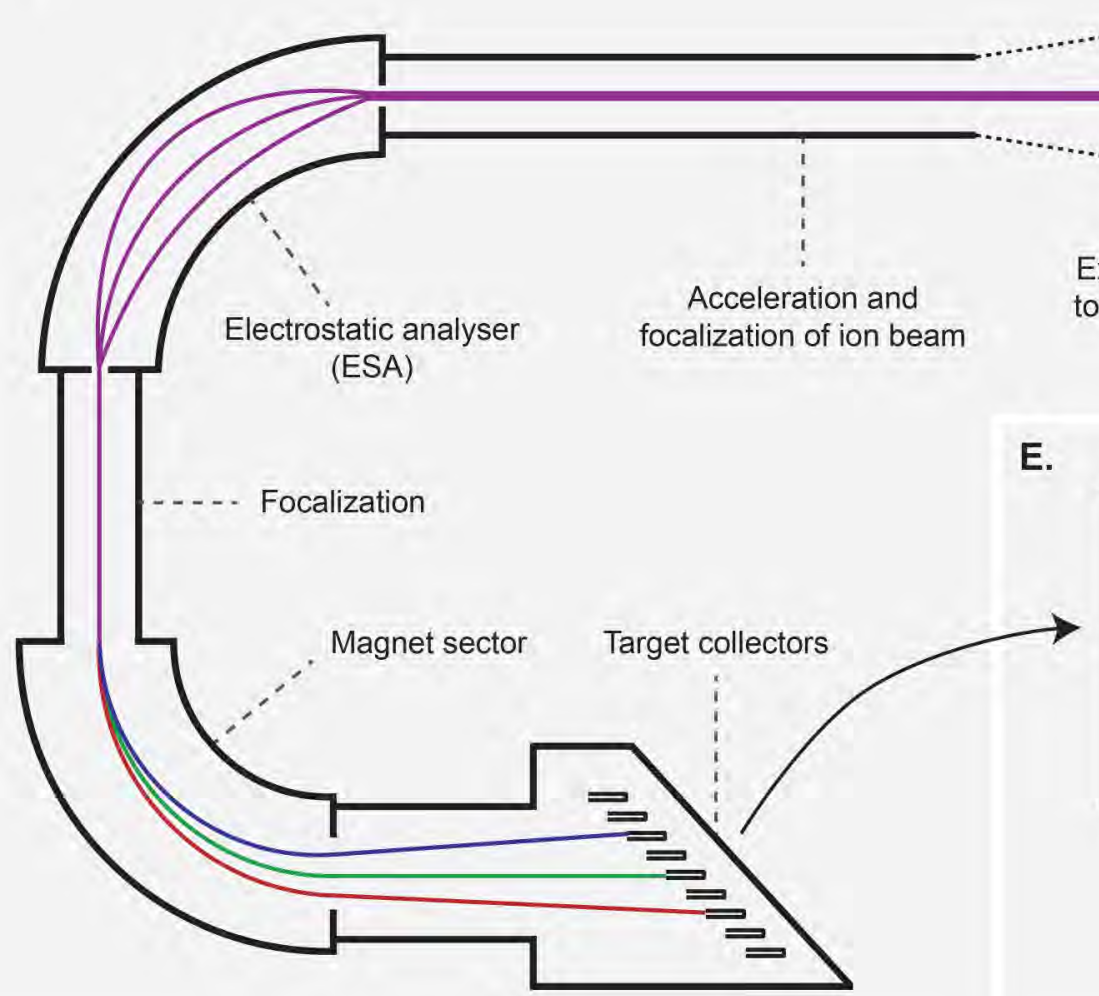

E.
C.

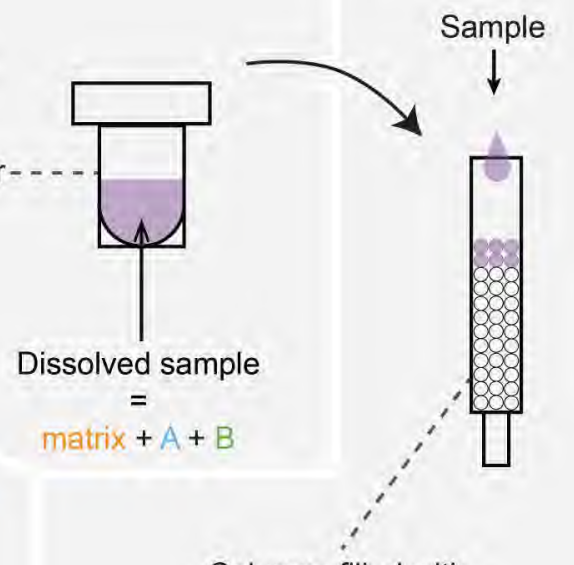

Columns filled with ion exchange resin

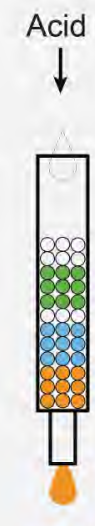

matrix out
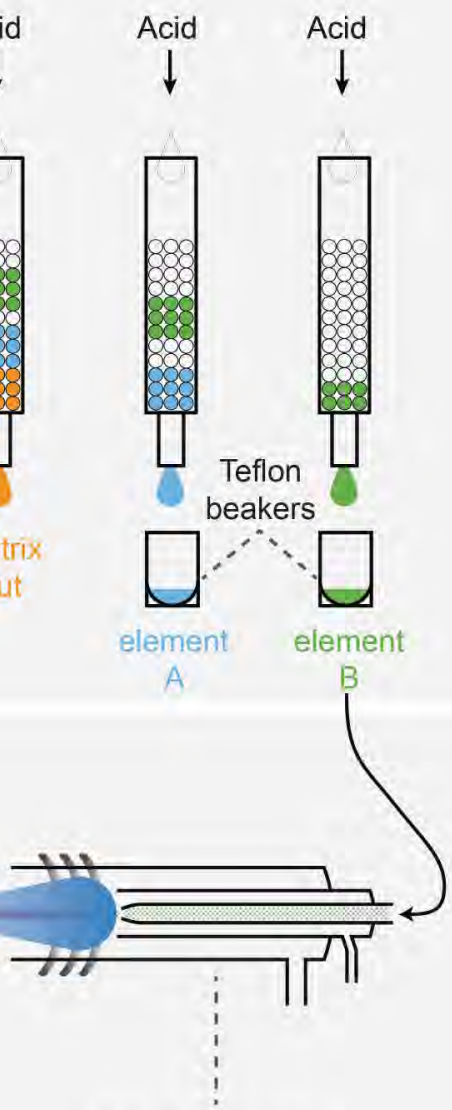

Introduction into argon plasma
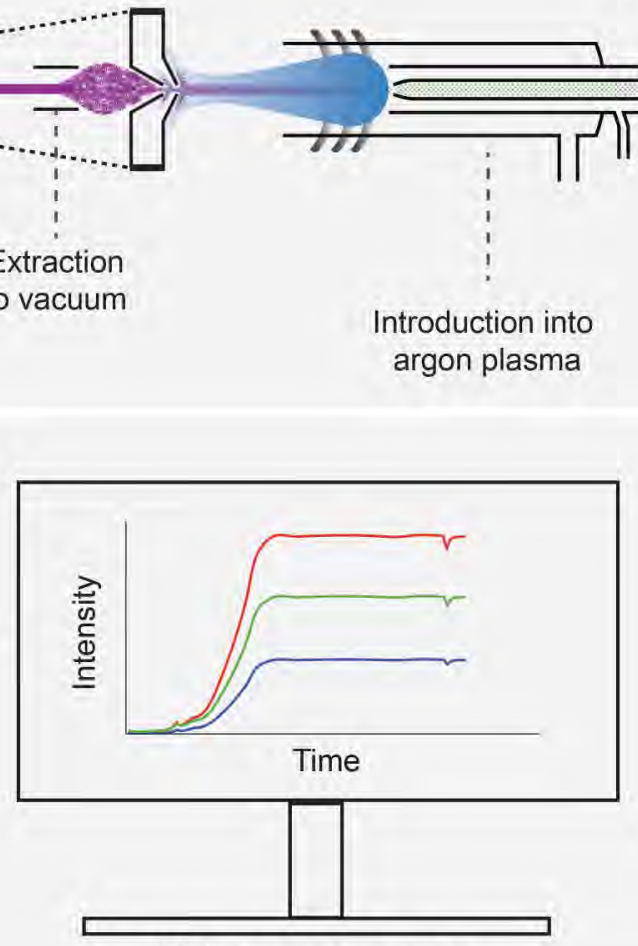

Voltage measurement and isotopic ratios calculation 


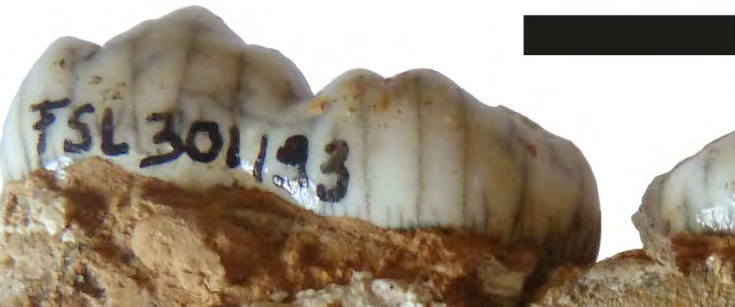

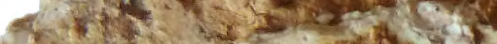



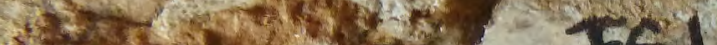

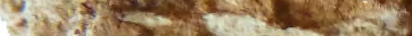


21

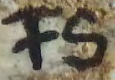


case 1

case 2

mini sampling equiv. bone collagen sampling concentration amount required for 1 millig of bioapatite 250 millig of bioapatite in bioapatite 1 measure on ICPMS $\mathrm{n}$ measures $\mathrm{n}$ measures

\begin{tabular}{ccccc} 
Ca & $40 \%$ & $2 \mu g$ & 100 & 25000 \\
\hline Mg & 2000 to $10000 p p m$ & $0.2 \mu g$ & 10 to 50 & 400 to 12500 \\
\hline Cu & $10 p p m$ & $0.4 \mu g$ & not measurable & 40 \\
\hline Fe & $100 p p m$ & $0.4 \mu g$ & not measurable & 400 \\
\hline $\mathbf{Z n}$ & $100 p p m$ & $0.4 \mu g$ & not measurable & 400 \\
\hline
\end{tabular}




\begin{tabular}{|c|c|c|c|c|c|c|c|}
\hline & \multicolumn{2}{|c|}{ Bone } & \multicolumn{2}{|c|}{ Rivers } & \multicolumn{2}{|c|}{ Seawater } & \\
\hline & $\mu \mathrm{g} / \mathrm{g}$ & $\%$ & $\mu \mathrm{g} / \mathrm{g}$ & $\%$ & $\mu \mathrm{g} / \mathrm{g}$ & $\%$ & \\
\hline Mg & 5000 & $\sim-1$ & $1 \_20$ & $-0.3_{-}-1.5$ & 1300 & $-2-0$ & Tipper et al., 2006 \\
\hline & 380000 & $\sim-1$ & $15 \_150$ & $+0.9 \_+2$ & 400 & $\sim+2$ & Tipper et al., 2016 \\
\hline Fe & 100 & $-1 \_0$ & $10_{-}^{-} 40$ & $-1 \_+0.3$ & 0.003 & $-2+0.3$ & John and Adkins, 2010; Bergquist \& Boyle, 2006 \\
\hline$C l$ & 10 & $-1 \_0$ & $1 \_10$ & $+0.1_{-}+1.3$ & 0.001 & $+0.5 \_+1.4$ & Vance et al, 2008 \\
\hline & 100 & $0 \_+2$ & $10 \_20$ & $+0.1_{-}+0.3$ & 0.005 & $-0.1_{-}^{-}+0.2$ & Bermin et al., 2006 \\
\hline
\end{tabular}

BERGQUIST, B.A., BOYLE, E.A. 2006. Iron isotopes in the Amazon river system: weathering and transport signatures. Earth and Planetary Science Letters 248, 54-68. BERMIN J VANCE, D, ARCHER, C. STAHAM, P. 2006. The determination of the isotopic composition of Cu and Zn in seawater. Chemical Geology 226, 280-297.

JOHN, S.G., ADKINS, J.F. 2010. Analysis of dissolved iron isotopes in seawater. Marine Geochemistry 119, 65-76.

TIPPER, E.T., GALY, A., GAILLARDET, J., BICKLE, M.J., ELDERFIELD, H., CARDER, E.A. 2006. The magnesium isotope budget of the modern ocean: constraints from riverine magnesium isotope ratios. Earth and Planetary Science Letters 250, 241-253. TIPPER, E.T., SCHMITT, A.D., GUSSONE, N. 2016. Global Ca cycles: coupling of continental and oceanic processes. In Nikolaus Gussone Ed. Calcium Stable Isotope Geochemistry. Springer-Verlag, 173-211.

VANCE, D., ARCHER, C., BERMIN, J, PERKINS, J, STAHAM, P.J, LOHAN, M.C., ELLWOOD, M J., MILLS, R.A. 2008. The copper isotope geochemistry of rivers and the oceans. Earth and Planetary Science Letters 274, 204-213.

Table S1. Data from the literature used in the model of the water/rock ratio presented in Fig. 2 


\begin{tabular}{|c|c|c|c|c|c|c|c|c|c|c|c|c|c|c|c|c|c|c|c|c|}
\hline $\begin{array}{l}\text { curation number } \\
\text {. }\end{array}$ & lab name & locality & $\begin{array}{l}\text { taxon } \\
\text { (a) }\end{array}$ & tissue & tooth type & $\delta^{-44 / 42} \mathrm{Ca}(\%)$ & 2SD & ${ }^{83 / 42} \mathrm{Ca}(\%)$ & 2SD n & $\mathrm{Mg}(\mathrm{ppm})$ & $\mathrm{Ca}(\%)$ & $P(\%)$ & $\mathrm{Ca} / \mathrm{P}$ & $\mathrm{Sr}(\mathrm{ppm})$ & $\mathrm{Ba}(\mathrm{ppm})$ & $\mathrm{Zn}(\mathrm{ppm})$ & $\mathrm{Mn}(\mathrm{ppm})$ & $\delta^{13} \mathrm{C}(\%)(1)$ & $\delta^{15} \mathrm{~N}(\%)(1)$ & $\mathrm{C} / \mathrm{N}$ \\
\hline $\begin{array}{l}\text { Sc83.282 } \\
\text { Sc89.94 }\end{array}$ & $\begin{array}{l}\text { sc3 } \\
\text { sc10 }\end{array}$ & $\begin{array}{l}\text { Sclayn, Belgium } \\
\text { Sclayn Belaium }\end{array}$ & $\begin{array}{l}\text { Bison priscus } \\
\text { Bison priscus }\end{array}$ & bone & - & $\begin{array}{l}-1.15 \\
-1.12\end{array}$ & 0.01 & $\begin{array}{l}-0.60 \\
-0.57\end{array}$ & $\begin{array}{l}0.033 \\
0.053\end{array}$ & $\begin{array}{l}303 \\
23\end{array}$ & $\begin{array}{l}16.7 \\
118\end{array}$ & $\begin{array}{l}7.9 \\
59\end{array}$ & 2.1 & $\begin{array}{l}124 \\
81\end{array}$ & 22 & 141 & 111 & -19.9 & 5.3 & 3.1 \\
\hline $\begin{array}{l}\text { Sc89.94 } \\
\text { Sc86.21 }\end{array}$ & & $\begin{array}{l}\text { Sclayn, Belgium } \\
\text { Sclavn Belaimm }\end{array}$ & Bison priscus & bone & & -1.12 & 0.01 & -0.57 & 0.053 & 231 & 11.8 & 5.9 & 2.0 & 81 & 291 & 146 & 2466 & -20.5 & 4.8 & 3.2 \\
\hline $\begin{array}{l}\text { Sc86.21 } \\
\text { Sc83.93 }\end{array}$ & $\begin{array}{l}\text { sc14 } \\
\text { sc1 }\end{array}$ & $\begin{array}{l}\text { Sclayn, Belgium } \\
\text { Sclayn, Belgium }\end{array}$ & $\begin{array}{l}\text { Bison priscus } \\
\text { Crocuta crocuta }\end{array}$ & bone & - & -0.97 & 0.06 & -0.47 & $\begin{array}{l}0.093 \\
3\end{array}$ & 177 & 13.5 & 6.5 & 2.1 & 86 & 8 & 98 & 29 & -20.5 & 4.3 & 3.2 \\
\hline Sc83.93b & sc9 & Sclayn, Belgium & Crocuta crocuta & $\begin{array}{l}\text { Done } \\
\text { bone }\end{array}$ & - & $\begin{array}{l}-1.33 \\
-1.23 \\
\end{array}$ & 0.03 & $\begin{array}{l}-0.65 \\
-0.59\end{array}$ & $\begin{array}{l}0.073 \\
0.073\end{array}$ & $\begin{array}{l}502 \\
317\end{array}$ & $\begin{array}{l}17.5 \\
16.1\end{array}$ & $\begin{array}{l}8.0 \\
76\end{array}$ & 2.2 & 99 & 49 & $\begin{array}{l}49 \\
84\end{array}$ & $\begin{array}{c}93 \\
582\end{array}$ & -19.7 & 115 & \\
\hline c89.135 & sc5 & Sclayn, Belgium & Equus caballus & bone & - & -0.93 & 0.01 & -0.49 & 0.063 & 409 & 14.1 & 6.9 & 2.0 & 97 & $\begin{array}{l}48 \\
65\end{array}$ & $\begin{array}{l}84 \\
85\end{array}$ & $\begin{array}{c}582 \\
45\end{array}$ & $\begin{array}{l}-1.4 \\
-21.7\end{array}$ & 5.1 & 3.1 \\
\hline Sc87.140 & $s c 6$ & Sclayn, Belgium & Equus caballus & bone & - & -1.18 & 0.0 & -0.62 & 0.09 & 160 & 7.9 & 3.8 & 2.1 & 53 & 69 & 76 & 198 & -21.7 & 5.2 & 3.2 \\
\hline Sc85.121 & sc17 & Sclayn, Belgium & Mammuthus primigenius & bone & - & -1.39 & $0.10>>>$ & -0.70 & 0.083 & 619 & 17.4 & 8.4 & 2.1 & 123 & 34 & 54 & 139 & -21.5 & 9.4 & 3.2 \\
\hline Sc81.205 & sc7 & Sclayn, Belgium & Coelodonta antiquitatis & bone & - & -0.93 & 0.06 & -0.47 & 0.073 & 203 & 9.8 & 4.5 & 2.2 & 86 & 36 & 88 & 259 & -20.6 & 5.5 & 2 \\
\hline Sc82.210 & sc8 & Sclayn, Belgium & Coelodonta antiquitatis & bone & - & -0.86 & 0.03 & -0.46 & 0.043 & 271 & 15.5 & 7.4 & 2.1 & 111 & 59 & 165 & 786 & -20.9 & 5.5 & 3.2 \\
\hline Sc85.94 & sc16 & Sclayn, Belgium & Ursus arctos & bone & - & -1.14 & 0.08 & -0.59 & 0.163 & 302 & 15.3 & 8.2 & 1.9 & 97 & 9 & 50 & 3 & -20.2 & 7.1 & 3.2 \\
\hline Sc82.131 & sc4 & Sclayn, Belgium & Ursus spelaeus & bone & t & -0.91 & 0.12 & -0.47 & 0.153 & 227 & 11.8 & 5.3 & 2.2 & 86 & 129 & 140 & 107 & -21.8 & 3 & 3.2 \\
\hline Sc86.136 & sc11 & Sclayn, Belgium & Ursus spelaeus & bone & - & -0.92 & 0.04 & -0.49 & 0.093 & 75 & 4.4 & 2.1 & 2.1 & 30 & 29 & 88 & 45 & -22 & 6.1 & 3.2 \\
\hline Sc83.63b & sc12 & Sclayn, Belgium & Ursus spelaeus & bone & - & -0.92 & 0.07 & -0.46 & 0.093 & 379 & 11.4 & 5.3 & 2.1 & 72 & 125 & 117 & 218 & -22.5 & 7 & 3.2 \\
\hline Sc83.295 & sc13 & Sclayn, Belgium & Ursus spelaeus & bone & - & -0.98 & 0.02 & -0.45 & $0.07 \quad 3$ & 221 & 15.6 & 7.4 & 2.1 & 96 & 9 & 72 & 2 & -23 & 6.5 & 3.2 \\
\hline Sc87.103 & sc15 & Sclayn, Belgium & Ursus spelaeus & bone & - & -1.07 & 0.02 & -0.54 & 0.043 & 283 & 14.5 & 6.9 & 2.1 & 79 & 59 & 135 & 271 & -21.8 & 5.1 & 32 \\
\hline Sc87.171 & sc18 & Sclayn, Belgium & Ursus spelaeus & bone & - & -0.98 & 0.04 & -0.52 & 0.103 & 368 & 14.6 & 6.9 & 2.1 & 85 & 9 & 115 & 11 & -22.2 & 6 & 3.2 \\
\hline UCBL-FSL 452157 & 452157 & Jaurens, France & Bison priscus & enamel & $\mathrm{m} 3$ & -1.42 & 0.08 & -0.73 & 0.163 & 1686 & 17.7 & 9.1 & 1.9 & 107 & 88 & 208 & 23 & - & - & - \\
\hline & 452144 & Jaurens, France & Bison priscus & enamel & $\mathrm{m} 3$ & -1.47 & 0.05 & -0.75 & 0.063 & 1274 & 26.3 & 13.7 & 1.9 & 173 & 107 & 98 & 17 & - & - & - \\
\hline UCBL-FSL 452150 & 452150 & Jaurens, France & Bison priscus & enamel & $\mathrm{m} 3$ & -1.38 & 0.04 & -0.72 & & 1620 & 34.0 & 17.7 & 1.9 & 138 & 90 & 162 & 108 & - & - & - \\
\hline UCBL-FSL 300448 & 300448 & Jaurens, France & Canis lupus & enamel & p3 & -1.46 & 0.09 & -0.74 & 0.033 & 1857 & 33.8 & 15.7 & 2.1 & 133 & 23 & 145 & 16 & - & - & - \\
\hline UCBL-FSL 300432 & 300432 & Jaurens, France & Canis lupus & enamel & $\mathrm{cor} C$ & -1.57 & 0.09 & -0.86 & 0.143 & 1219 & 30.4 & 14.8 & 2.1 & & 16 & & 15 & - & - & - \\
\hline UCBL-FSL 300433 & 300433 & Jaurens, France & $\begin{array}{l}\text { Canis lupus } \\
\text { ateta }\end{array}$ & enamel & cor C & -1.54 & 0.08 & -0.75 & 0.053 & 1296 & 38.6 & 19.8 & 2.0 & 102 & 13 & 39 & 5 & - & - & - \\
\hline UCBL-FSL 309010 & $\begin{array}{l}309010 \\
306015\end{array}$ & Jaurens, France & Coelodonta antiquitatis & enamel & $\mathrm{P}$ & $\begin{array}{r}-1.14 \\
1.22\end{array}$ & 0.13 & $\begin{array}{l}-0.60 \\
\end{array} y=$ & 0.164 & $\begin{array}{l}1129 \\
1019\end{array}$ & $\begin{array}{r}32.5 \\
33.3\end{array}$ & 17.1 & 1.9 & 420 & 37 & $14+2+2$ & 159 & - & - & - \\
\hline $\begin{array}{l}\text { UCBLL-FSL } 396015 \\
\text { UCBL-FSL } 396055\end{array}$ & $\begin{array}{l}396015 \\
396055\end{array}$ & $\begin{array}{l}\text { Jaurens, France } \\
\text { Jaurens. France }\end{array}$ & Coelodonta antiquitatis & $\begin{array}{l}\text { enamel } \\
\text { ename }\end{array}$ & $\mathrm{m}$ & $\begin{array}{l}-1.22 \\
-1.37\end{array}$ & 0.08 & $\begin{array}{l}-0.59 \\
\end{array}$ & $\begin{array}{r}0.234 \\
0.22\end{array}$ & $\begin{array}{l}1019 \\
1141\end{array}$ & 33.3 & $\begin{array}{l}17.6 \\
172\end{array}$ & $\begin{array}{l}1.9 \\
19\end{array}$ & $\begin{array}{l}296 \\
332\end{array}$ & 20 & 135 & 55 & - & - & - \\
\hline $\begin{array}{l}\text { UCBLLFSL } 396055 \\
\text { UCBL-FSL } 300601\end{array}$ & $\begin{array}{l}396055 \\
300001\end{array}$ & $\begin{array}{l}\text { Jaurens, France } \\
\text { Jaurens. France }\end{array}$ & Coelodonta antiquitatis & $\begin{array}{l}\text { enamel } \\
\text { enamel }\end{array}$ & $\mathrm{m}$ & $\begin{array}{l}-1.37 \\
-184\end{array}$ & 0.12 & -0.67 & 0.223 & $\begin{array}{l}1411 \\
1688\end{array}$ & $\begin{array}{r}32.0 \\
324\end{array}$ & 17.2 & $\begin{array}{l}1.9 \\
20\end{array}$ & 328 & $\begin{array}{c}30 \\
105\end{array}$ & $\begin{array}{c}45 \\
148\end{array}$ & $\begin{array}{l}24 \\
65\end{array}$ & - & - & - \\
\hline UCBL-FSL 300599 & 300599 & $\begin{array}{l}\text { Jaurens, France } \\
\text { Jaurens, France }\end{array}$ & $\begin{array}{l}\text { Crocuta crocuta } \\
\text { Crocuta crocuta }\end{array}$ & $\begin{array}{l}\text { enamel } \\
\text { enamel }\end{array}$ & $\begin{array}{l}\operatorname{cor} \mathrm{C} \\
\operatorname{cor} \mathrm{C}\end{array}$ & $\begin{array}{l}-1.84 \\
-1.85\end{array}$ & $\begin{array}{l}0.10 \\
0.08\end{array}$ & $\begin{array}{l}-0.91 \\
-0.92\end{array}$ & $\begin{array}{l}0.134 \\
0.033\end{array}$ & $\begin{array}{l}1688 \\
1696\end{array}$ & $\begin{array}{l}32.4 \\
35.2\end{array}$ & $\begin{array}{l}16.2 \\
17.8\end{array}$ & $\begin{array}{l}2.0 \\
2.0\end{array}$ & $\begin{array}{l}83 \\
107\end{array}$ & $\begin{array}{l}105 \\
37\end{array}$ & $\begin{array}{l}148 \\
151\end{array}$ & $\begin{array}{l}65 \\
32\end{array}$ & - & - & $=$ \\
\hline UCBL-FSL 300610 & 300610 & Jaurens, France & Crocuta crocuta & enamel & P3 & -1.87 & 0.09 & -0.93 & 0.073 & 958 & 37.1 & 18.6 & 2.0 & 81 & 34 & 319 & 181 & - & - & - \\
\hline UCBL-FSL 300583 & 300583 & Jaurens, France & Crocuta crocuta & enamel & p3 & -1.83 & 0.09 & -0.86 & 0.103 & 1664 & 32.0 & 15.8 & 2.0 & 117 & 32 & 75 & 44 & - & - & - \\
\hline UCBL-FSL 300573 & 300573 & Jaurens, France & Crocuta crocuta & enamel & P3 & -2.02 & 0.04 & -1.04 & 0.033 & 1760 & 33.4 & 17.2 & 1.9 & 108 & 55 & 299 & 29 & - & - & - \\
\hline UCBL-FSL 301061 & 301061 & Jaurens, France & Panthera pardus & enamel & P3 & -1.92 & 0.02 & -0.95 & 0.103 & 1962 & 34.1 & 16.4 & 2.1 & 55 & 28 & 109 & 171 & - & - & 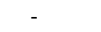 \\
\hline UCBL-FSL 301081 & 301081lea & Jaurens, France & Panthera pardus & leached bone & - & -1.52 & 0.03 & -0.7 & 0.153 & 212 & 26.5 & 13.7 & 1.9 & 23 & 17 & 695 & 356 & - & - & - \\
\hline SLL 301081 & 30108 & Jaurens, France & Panthera pardus & bone & & -1.3 & 0.11 & -0.7 & 0.093 & 360 & 23.8 & 11.4 & 2.1 & 10 & 34 & 857 & 624 & - & - & - \\
\hline UCB & 300918lea & Jaurens, France & Panthera spelaea & leached enamel & $c(r)$ & -1.4 & 0.04 & -0.7 & 0.083 & 91 & 20.4 & 10.8 & 1.9 & 3 & 9 & 0 & 16 & - & - & - \\
\hline UCE & 3 & Jaurens, France & Panthera spelaea & enan & $c(r)$ & -1 & 0.06 & -0 . & & 22 & 31.8 & 15.9 & 2.0 & & 23 & 23 & 60 & - & - & - \\
\hline & 3 & Jaurens, France & spelaea & en & $\mathrm{m} 1(\mathrm{r})$ & -1. & $0 . c$ & -0 . & & 24 & & 16.3 & 2.0 & & & & 27 & - & - & - \\
\hline UCE & 3008 & Jaurens, France & ra spel & enan & $c(1)$ & -1.4 & 0.05 & -0. & 0.083 & 21 & 32.6 & 16.4 & 2.0 & 176 & 65 & 166 & 150 & - & - & - \\
\hline UCE & 3009 & Jaurens, France & Pan & enar &  & -1.5 & 0.11 & -0 & 0.033 & 13 & 34.5 & 16.7 & 2.1 & & 3 & 104 & & - & - & - \\
\hline L L 451263 & 4512 & Jaurens, France & Ran & enar & M2 (r) & -1.5 & 0.09 & -0.7 & 0.14 & 15 & 33.5 & 16.9 & 2.0 & 16 & 77 & & 28 & - & - & - \\
\hline UCBL-FSL 451271 & 451271 & Jaurens, France & Rans & enar & M2 (r) & -1.7 & 0.07 & -0.8 & 0.13 & 222 & 33.9 & 17.0 & 2.0 & 200 & $86>>2>>$ & 149 & 23 & - & - & - \\
\hline UCBL-FSL 451267 & $\begin{array}{l}451267 \\
3\end{array}$ & Jaurens, France & Rangifer tarandus & & M2 (r) & -1.7 .7 & 0.09 & 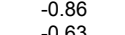 & 0.043 & $\begin{array}{l}1003 \\
178\end{array}$ & $\begin{array}{r}45.5 \\
36.4\end{array}$ & 23.8 & 1.9 & 287 & 160 & 11 & 6 & - & - & - \\
\hline $\begin{array}{l}\text { UCBLLFSL } 30121010 \\
\text { UCBLLFS L } 01193\end{array}$ & $\begin{array}{l}301210 \\
301193\end{array}$ & $\begin{array}{l}\text { Jaurens, France } \\
\text { Jaurens. France }\end{array}$ & $\begin{array}{l}\text { Ursus arctos } \\
\text { Ursus arctos }\end{array}$ & $\begin{array}{l}\text { enamel } \\
\text { enamel }\end{array}$ & $\begin{array}{l}\mathrm{P} 4 \\
\mathrm{~m} 2\end{array}$ & $\begin{array}{l}-1.29 \\
-1.23\end{array}$ & 0.05 & $\begin{array}{r}-0.63 \\
-0.58\end{array}$ & 0.113 & 1678 & 36.4 & $\begin{array}{l}18.3 \\
164\end{array}$ & 2.0 & 110 & $\begin{array}{r}59 \\
25\end{array}$ & 111 & 367 & - & - & $-\theta^{-1}$ \\
\hline $\begin{array}{l}\text { UCBLLFSL } 3011193 \\
\text { UCBLLFS L } 0191190\end{array}$ & $\begin{array}{l}301193 \\
301190\end{array}$ & $\begin{array}{l}\text { Jaurens, France } \\
\text { Jaurens. France }\end{array}$ & $\begin{array}{l}\text { Ursus arctos } \\
\text { Ursus arctos }\end{array}$ & $\begin{array}{l}\text { enamel } \\
\text { enamel }\end{array}$ & $\begin{array}{l}\mathrm{m} 2 \\
\mathrm{M} 2\end{array}$ & $\begin{array}{l}-1.23 \\
-1.23\end{array}$ & $\begin{array}{l}0.15 \\
0.08\end{array}$ & $\begin{array}{l}-0.58 \\
-0.60\end{array}$ & $\begin{array}{l}0.124 \\
0.134\end{array}$ & $\begin{array}{l}1156 \\
1564\end{array}$ & $\begin{array}{l}33.0 \\
34.3\end{array}$ & $\begin{array}{l}16.4 \\
178\end{array}$ & 2.0 & 96 & $\begin{array}{r}25 \\
22\end{array}$ & $\begin{array}{r}69 \\
114\end{array}$ & 66 & - & - & - \\
\hline UCBL-FSL 301217 & 301217 & $\begin{array}{l}\text { Jaurens, France } \\
\text { Jaurens, France }\end{array}$ & $\begin{array}{l}\text { Ursus arctos } \\
\text { Ursus arctos }\end{array}$ & $\begin{array}{l}\text { enamel } \\
\text { enamel }\end{array}$ & $\mathrm{m} 2(\mathrm{r})$ & $\begin{array}{l}-1.23 \\
-1.12\end{array}$ & 0.11 & $\begin{array}{l}-0.00 \\
-0.56\end{array}$ & $\begin{array}{l}0.134 \\
0.093\end{array}$ & $\begin{array}{l}1654 \\
1691\end{array}$ & $\begin{array}{l}34.3 \\
33.3\end{array}$ & $\begin{array}{l}11.8 \\
16.2\end{array}$ & $\begin{array}{l}1.9 \\
2.1\end{array}$ & $\begin{array}{l}110 \\
55\end{array}$ & 26 & $\begin{array}{c}114 \\
80\end{array}$ & $\begin{array}{l}123 \\
19\end{array}$ & - & - & $=$ \\
\hline UCBL-FSL 300610 & $300610 \mathrm{c}$ & Jaurens, France & calcite crust & sediment & & -0.28 & 0.05 & -0.13 & 0.133 & 364 & 34.5 & 0.0 & 2. & 12 & 10 & 6 & 49 & - & - & 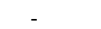 \\
\hline NIST SRM1486 & SRM14 & & standard & bone & - & -1.07 & 0.02 & -0.5 & 0.012 &  & - & - & - & - & - & - & - & - & - & - \\
\hline NIST SRM1486 & SRM1486 of & - & stan & bor & - & -0 . & 0. & -0.5 & 0.264 & - & - & - & - & - & - & - & - & - & - & - \\
\hline NIST SRM1486 & SRM1486 0616 \#3 & 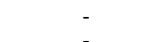 & standard & bone & - & -1.02 & 0.10 & -0.57 & 0.086 & - & - & 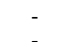 & - & &  & - & & - & - & \\
\hline NIST SRM1486 & SRM1486 $0516 \# 3$ & & standard & bone & & -0.97 & 0.07 & -0.50 & & & & & & & & & & & & \\
\hline
\end{tabular}

Table 2. Calcium isotope values (expressed as $844 / 42 \mathrm{Ca}$ and $843 / 42 \mathrm{Ca}$ (in \%) relative to standard ICP Ca-Lyon) measured on two Pleistocene trace elements. (1) $\delta 13 \mathrm{C}$ and $\delta 15 \mathrm{~N}$ values and C/N ratios from Bochoerens et al. 1997.
Tooth type: capital letters refer to the upper tooth row. 